\title{
Some Reflections on Student Movements of the 1960s and Early 1970s
}

Some Reflections on Student Movements of the 1960s and Early 1970s

Quelques réflexions sur les mouvements étudiants des années soixante et du commencement des années soixante-dix

Colin Barker

\section{(2) OpenEdition}

Electronic version

URL: https://journals.openedition.org/rccs/646

DOI: $10.4000 /$ rccs.646

ISSN: 2182-7435

Publisher

Centro de Estudos Sociais da Universidade de Coimbra

\section{Printed version}

Date of publication: 1 June 2008

Number of pages: $43-91$

ISSN: 0254-1106

\section{Electronic reference}

Colin Barker, "Some Reflections on Student Movements of the 1960s and Early 1970s", Revista Crítica de Ciências Sociais [Online], 81 | 2008, Online since 01 October 2012, connection on 07 December 2022. URL: http://journals.openedition.org/rccs/646 ; DOI: https://doi.org/10.4000/rccs.646

Creative Commons - Attribution 4.0 International - CC BY 4.0

https://creativecommons.org/licenses/by/4.0/ 


\section{COLIN BARKER}

\section{Some Reflections on Student Movements of the 1960s and Early 1970s}

This article considers the rise and decline of student movements in Europe and America during the 1960 s and 1970 . Drawing on materials on student movements in a number of countries, it assesses their historical significance, in the context of a larger 'protest wave' with which the student movements of the period intersected. Relating these movements to students' changing position within advanced capitalism, it suggests that their dynamics were shaped both by the specific characteristics of students as political actors and by the patterns of their inter-relations with other contemporaneous movements. The article concludes by noting more recent developments, suggesting that the story of student movements still offers interesting new possibilities.

The 1960s and early 1970s were notable for the rise and spread of student movements across many parts of the industrialized world. There were two interconnected facets to student movements in this period. The first was the spread of movements on university and college campuses, protesting at specific regulations, policies and actions by the academic authorities. In some cases, although on a smaller scale, these movements also involved high school students. The second was the involvement of growing numbers of students in other significant movements of the period, notably on the Left. The two processes, in turn, influenced each other.

\section{Situating student movements}

Here I want to pose several questions about these developments. First, why did these movements appear when they did? Second, why did they take the forms they did? Third, how did they relate to other movements of the period? Fourth, what were their limits of development? And, fifth, what forces led to their decline and retreat?

Answers to questions posed in this form imply a historical analysis. In other words, they imply rejection of some of the explanations offered at the time for 'student revolt'. Neil Smelser and others, for example, interpreted student insurgency as a form of intergenerational battle, an Oedipal revolt 
of the sons against their fathers (Goodwin, Jasper and Polletta, 2001). This a-historical theory did not explain why it was only from 1964 onwards that students mobilized on college campuses, given that Oedipal urges are presumably rather more universal. Moreover, surveys of students who participated in these revolts suggested that their parents were more likely themselves to have liberal or radical backgrounds, and indeed to be relatively supportive of their offspring's political delinquency (Lipset and Altbach, 1967). Was student revolt perhaps the product of frustrations experienced by upwardly mobile working-class students (an explanation mentioned in Harman et al., 1968)? That didn't account for the upper-and middle-class origin of many of the student protestors. ${ }^{1}$ Nor, on the other hand, was the hostile idea, propounded by the French Communist Party or the Polish regime, that students were 'traditional middle class' any better, for that took no account either of the expanding numbers of students from working-class families or of the changing situation facing students in the labour market (Jones, 1969). Or perhaps it was the poor physical conditions experienced by many students in the rapidly expanding universities that drove them to revolt? There is no question that, often, facilities for the massively expanded numbers of students were indeed poor. ${ }^{2}$ The problem with that explanation is that, by and large, material conditions were not the issues that exercised student protestors in this period; rather, they raised questions about their own and others' civil and political rights and about such larger questions as America's war in Vietnam, and the authoritarian character of social institutions generally. Ginsborg writes of the Italian student revolt that ' $[\mathrm{t}]$ he year $1968[\ldots]$ was much more than a protest

\footnotetext{
${ }^{1}$ Bereday managed to combine the two in a splendidly biased account: 'All universities train the elites. In all appear sons of the elite firmly and securely bound to follow their fathers. In all appear also some sons of the "have nots" aware that their talent will carry them into the ranks of the elite. Such students rarely riot. The activists are rather a coalition of the splinters of these groups: sons of the elite who for some reason or for the time being don't want to join in, who instead want "to get even with their fathers"; and sons of the "have-nots" whose prospects of absorption into the elite are not secure or not attractive and who instead of "joining" elect to "lick" it. The coalition of these two groups is usually unbeatable. The rebel sons of the elite supply the know-how of how to operate and to rock the establishment. The rebel "have-nots" supply the fury and the determination to forge head which only those who have been "left out" can muster.' (Bereday, 1967: 120). ${ }^{2}$ At the beginning of 1968 there were 156,000 university students in Paris, but only 500 seats in the university library. 'Practical work in science laboratories is often done in batches of 40 or more, and it is not unknown for a small lecture room to be crammed with 500 students trying to take notes from one lecturer' (Cliff and Birchall, 1968: 214). By 1968, the three Italian universities of Rome, Naples and Bari, each designed for student populations of 5,000, contained 140,000 students between them. Italy's university lecturers were 'notorious absentees'; there were no seminars or tutorials and thus almost no staff-student contact. Most examinations were oral - Turin students described them as 'occasions when a policeman dressed up as a teacher spends five to ten minutes liquidating the accused with a series of questions.' Only half the students succeeded in graduating (Ginsborg, 1990: 299-300).
} 
against poor conditions. It was an ethical revolt, a notable attempt to turn the tide against the predominant values of the time' (Ginsborg, 1990).

An adequate account of student movements in the 1960s and early 1970s ought, in short, to take seriously what students themselves said and did. By comparison with later periods, for example, we can note that generally student movements did not raise demands about student finance: tuition fees, grants and the like. Nor did they protest - as French students did in $2006-$ at proposed legislation concerning their future employment prospects. Also, our account ought to attempt an explanation of why student movements appeared at the time they did, rather than at some other time. It was not the case that students suddenly discovered grievances about university administrations. When, at the beginning of the 1960s, for example, a man and a woman student at Oxford University were disciplined for being found in bed with each other, he was suspended for a short period while she was expelled permanently. There was a widespread sentiment among Oxford students that this application of a 'double standard' was grossly unjust, but no one suggested any collective action against the university authorities (not even a petition). Had the same thing happened six or seven years later, it would have been a likely casus belli. By then, also not only would the 'double standard' have been a contentious issue, but so would the authorities' claim to interfere in students' sexual lives. By then, too, the idea of protest at the university would have become familiar.

Taking seriously what students did and said suggests a rejection of explanations of student revolt, which rely either on the psycho-pathology of individual students or on some unmediated response to unsatisfactory material conditions. That argument, of course, owes much to the very developments in thinking about social movements that followed after the movements of the 1960s. Indeed, those developments were one of the student movements' intellectual results. The shift in styles of thinking is most notable within North American academic social science. Before and indeed during the initial wave of student campus protest, the predominant academic discourse about popular protest was that of 'collective behaviour'. Here the ruling presumption was that protest is an expression of anomie, irrationality and psychological disturbance. In the wake of the same movements, there was a major paradigm-shift within the academy, measurable in terms of a content-analysis of leading sociological journals (Morris and Herring, 1987). James B. Rule has suggested that the shift amounted to the closest thing in social science to an actual revolution (Rule, 1989). A cohort of graduate students and junior professors, who had themselves participated in or at least actively sympathized with the movements of the 1960s read the existing 
literature, found themselves, their activities and their sympathies written off as pathological, and set about remaking the discipline. ${ }^{3}$ If nothing else, student revolt altered the way we can now talk about it.

But if we are to explore, rather than reject, the specific rationality of student movements of the 1960s and early 1970s, we cannot do so without regard to other social, political, and cultural movements of the time. Student movements do not develop in isolation from wider social conflicts. To be sure, they may possess their own specific dynamics, as a product of their particular social composition and the situations of their emergence. But they are anything but immune to larger tendencies of development, to which they make their own contribution.

\section{A protest wave}

Considered in this light, the period under discussion was marked by a much larger, and diverse movement of protest, affecting a whole range of countries across the globe. Indeed, it makes sense to talk of an international 'protest wave' from, broadly, the mid-1960s to the mid-1970s, which encompassed much more than simply student movements.

The onset of such a protest wave is marked by a rise in the overall level of 'episodes of contention' - that is, of such phenomena as demonstrations, strikes, riots, occupations and the like - across the whole face of society. Moreover, it is not simply that there are more such episodes, but they involve more people.

Another term for this phenomenon, within the social movement literature, is a 'cycle of protest' (Tarrow, 1983, 1989a, 1989b, 1993, 1994). I prefer the term 'wave' to 'cycle', because of the potential risk that the phenomenon can be taken to mean something akin to the 'semi-automatic' cyclical processes familiar in economic studies. Protest waves seem to follow nothing like the regular ups and downs of economic cycles (Frank and Fuentes, 1984). Nor - more to the point - are their trajectories best understood as following the kinds of inevitable sequences once hypothesized by the 'natural history of revolution' (Brinton, 1965), or by the kind of 'metaphysical pathos' that Alvin Gouldner identified in Michels' account of the ever-repeating waves of popular insurgency (Gouldner, 1955). ${ }^{4}$ They

\footnotetext{
${ }^{3}$ There are notably clear critiques of the 'collective behaviour' tradition and arguments for alternatives in Aya, 1979; McAdam, 1988; McPhail, 1991.

${ }^{4}$ On Michels, see also Barker, 2001. Tarrow and his colleagues engage in something of an autocritique in their recent re-formulation of social movement theory: 'By positing a recurring parabolic shape to episodes of contention, cyclical theory begged the question of the internal composition of the cycle and whether there are episodes that take different forms altogether' (McAdam, Tarrow and Tilly, 2002: 66).
} 
are open-ended processes, containing varieties of possibility in terms of tempo, extent, degree of mobilization, inner configuration, outcome, and so on.

A protest wave is a phenomenon in its own right, and more than simply the sum of its parts (Tarrow, 1983). Two features are particularly notable in the present context. First, a protest wave is a period marked by high levels of innovation in, and rapid diffusion of what Charles Tilly has taught us to term 'repertoires of contention' (Tilly, 1978, 1993, 1995). One process associated with the development of new tactics of struggle and of organizing is the entry into the field of protest of new social forces and new issues. Here, the growth of student protest played a significant part. Second, there is an intimate and dynamic relation between the different movements that comprise the overall development of the protest wave. So, for example, in the United States (which played an exceptional part in initiating the overall protest wave), there was an ongoing interaction between the civil rights movement and student protest on the campuses, between both of these and the developing movement against the American war in Vietnam, and in turn between all of these and both workers' movements on the shop floor and the emerging women's movement. The various 'parts' both stimulate and constrain each other in their onward development.'

The protest wave of the 1960s and 1970s was, notably, an international phenomenon. It had a novel feature, compared with earlier such waves, like those around the 1848 revolutions in Europe or the explosions of popular protest that marked and followed the end of the First World War. The novel element was the role of student struggles. In earlier periods, students were more commonly found on the side of reaction. June 1848 in Paris saw students on the 'bourgeois' side of the barricades; ${ }^{6}$ likewise in the revolutions of 1917-19 in Europe. During the British general strike of 1926, university students were remembered chiefly as strike-breakers. Students were not notable contributors to anti-fascism in interwar Europe. By the 1960s, however, matters were different. Although there were some right-wing student mobilizations, they were not the predominant pattern. Rather, a widespread link was assumed between student activism and radicalism and even revolutionism.

\footnotetext{
5 The 'reciprocal action' between different parts of a movement was a feature of earlier movements. Perhaps the first writer to draw attention to this was the Polish-German revolutionary, Rosa Luxemburg, writing about mass strikes in Russia (Luxemburg, 1986).

${ }^{6}$ When students did participate in the struggle against absolutism during the 1848 revolutions, Marx and Engels were rather scornful about their reliability: see the discussion in Draper, 1978: 534-8.
} 
However, even though that element was new, it was only part of a larger overall picture. Thus, for example, international indices of workers' involvement in strikes also rose during the period 1965-75, although to varying degrees in different countries. ${ }^{7}$

\section{The global context}

What kind of world engendered the international protest wave? It was, in a number of significant respects, rather different from today. Firstly, the postwar world economy experienced the longest and most continuous boom in the history of industrial capitalism. The boom induced extensive changes in the social structure. There was a very marked expansion in the numbers of 'white-collar' workers, while huge numbers of workers were drawn off the land and into the cities. Factory and office work both expanded as the agricultural work-force declined. One political effect was to undermine the social bases of 'old conservatism', rooted in large peasantries. Another effect was that almost continuous full employment within industrial nations engendered, on the one hand, working-class confidence and readiness to take strike action along with, on the other hand, a relatively low tendency to political generalization.

Sustained economic growth was widely attributed to wise management by governments, who played an unprecedently large role in directing their domestic economies. Not only did welfare spending rise, but governments were directly involved in various forms of investment direction, both within extensive nationalized industrial sectors and also in collaboration with leading private corporations. Such state involvement was, indeed, assumed to be an essential feature of economic growth, not only in the 'communist' economies but also in the West, where Keynesian thinking provided the predominant doctrine of political economy.

Within the social sciences, dominant discourses stressed social stability. If a rather self-satisfied Keynesianism ruled in economics, Talcott Parsons's structural functionalism provided the major paradigm within sociology. 'The withering away of the strike', 'the end of ideology', the self-supercession of capitalism by a new managerialism, the decline of class: such themes were confidently and regularly rehearsed. Even the confrontation between Western 'capitalism' and Russian 'communism' was expected to soften through 'convergence', with the West moving towards greater state planning and the East, after Stalin, moving towards greater liberalization. Even on the Left, most writers who were critical of the system also emphasized the

\footnotetext{
${ }_{7}$ See, for example, Crouch and Pizzorno, 1978.
} 
underlying stabilization of social relations. They too stressed the institutionalization of collective bargaining, and the de-radicalization (even 'embourgeoisement') of the working class under the dual impact of rising living standards and modern mass media. Herbert Marcuse's One-Dimensional Man, though deeply antagonistic to the societies of both East and West, saw human liberation now under the lock and key of modern technology:

Technical progress, extended to a whole system of domination and coordination, creates forms of life (and power) which appear to reconcile forces opposing the system. An overriding interest in the preservation and improvement of the institutional status quo united the former antagonists (bourgeoisie and proletariat) in the most advanced areas of contemporary society. [...] The 'people', previously the ferment of social change, have 'moved up' to become the ferment of social cohesion. (Marcuse, 1964)

The only hope for change lay with 'the substratum of the outcasts, the exploited, the persecuted of other races and other colours, the unemployed and the unemployable' (Marcuse, 1964: 256). In like manner, C. Wright Mills, and later Paul Baran and Paul Sweezy, denied that the working class in advanced capitalism any longer offered any radical threat (Baran and Sweezy, 1966; Mills, 1960). For them, the best hope for change lay with either liberal intellectuals or the anti-colonial revolutions in the Third World. The French theorist of the 'new working class', Andre Gorz, went so far as to declare, in early 1968, 'in the foreseeable future there will be no crisis of European capitalism so dramatic as to drive the mass of workers to revolutionary general strikes' (Gorz, 1968). ${ }^{8}$ In this period, the official Left parties were pulling to the Right: the parties of the Second International were abandoning the old talk of 'socialism' while western Communist Parties were adopting 'parliamentary roads'. As for the revolutionary Left, it was tiny and utterly marginal.

There were, nonetheless, within this seemingly endless expansion and containment, significant contradictions at work. Growth within the 'communist' bloc was gradually slowing, with Czechoslovakia actually experiencing a short recession in 1963; nationalist tensions were growing, most markedly in the emerging Sino-Soviet split. In the West, beneath the umbrella of US economic and military hegemony, West Germany, France,

\footnotetext{
${ }^{8}$ Gorz had the misfortune to see his article appear in English in May 1968, just as Europe's largest ever general strike was breaking out!
} 
Italy and Japan all experienced 'economic miracles' that sharpened competition for markets and slowly undermined the position of the dollar. Within western nation-states, growing concern about maintaining economic competitiveness spurred state planning forward. It was just that concern which fuelled the huge expansion of investment in universities from the early 1960s.

Secondly, national liberation struggles were still being fought fiercely in the still considerable remnants of the old colonial empires. One of these, the Vietnamese struggle to reunify their country, fuelled the most important international conflict of the later 1960s and early 1970s, the bitter and costly American war in Vietnam (and later Cambodia).

Thirdly, if mainstream sociology spoke of the inevitable link between industrial progress and liberal democracy, the analysis only fitted 'the north' of western capitalism. Sectors of the western industrialized world were still dominated by undemocratic, authoritarian regimes. In Europe, Spain and Portugal remained under the heel of pre-war fascist regimes, while in Greece a military coup in 1967 put paid to democracy. In Northern Ireland the Orange state systematically discriminated against Roman Catholics. Perhaps, though, most significant was the situation in the southern states of the USA, where the old racist system of Jim Crow segregation still excluded most Blacks from voting and from anything approaching equal civil rights. Jim Crow began only a few miles south of Washington, capital of the most powerful nation-state in the world. It was here, above all, 'in the belly of the beast', that the first major impulses of the protest wave were registered. They would soon draw students in.

\section{University expansion}

This post-1945 world produced a huge expansion in post-secondary education. Increasingly, industrial capitalism required, not just a qualified elite, but a growing mass of individuals who could be trained to become 'white-collar' workers, performers of 'mental labour': scientists, technologists, administrators and managers, lawyers, teachers, social workers, and so on. This was the fastest expanding sector of the workforce, whose pay and working conditions were slowly converging towards those of 'skilled manual' workers.

The USA had been the pioneer of 'mass' higher education: by the late 1960s, 30 per cent of the age-group was in college (Jones, 1969: 32). Some American educational administrators were remarkably blunt about what they saw as the functions of the modern university: John Hannah, President of Michigan State, declared in September 1961, '[o]ur colleges and universities must be regarded as bastions of our defence, as essential to preserva- 
tion of our country and our way of life as super-sonic bombers, nuclear powered submarines and intercontinental ballistic missiles'. Clark Kerr, soon to become famous through his role in confronting campus protest at Berkeley, argued, 'the university has become a prime instrument of national purpose. This is new. This is the essence of the transformation now engulfing our universities' (Davidson, 1969). Kerr coined the term 'multiversity' to define the new giant institutions, which should, he said, be thought of as 'knowledge factories'?

In this field, where America led, the other major industrial powers followed rapidly. The West German 'economic miracle' demanded a changed labour force. Employer organizations voiced their concerns about expected shortages of skilled and white-collar workers and their general need for a more knowledgeable workforce. The Bonn government moved to overcome the projected labour shortfall by dramatically expanding post-secondary education, increasing subsidies for students, and opening universities to applicants from broader social backgrounds. The number of universities increased from 112 in 1950 to 735 in 1980, the numbers of students in post-secondary schools grew by 500 per cent between 1950 and 1975. By close of 1970s, West Germany possessed an unusually well educated workforce, with almost half its wage earners in 'white collar' jobs (Zirakzadeh, 2006). In the process, the social composition of the working class was dramatically altering.

In Italy, the number of university students grew from 268,000 in 1960 to over 450,000 in 1968 (Ginsborg, 1990: 299). In Britain, where state spending on universities in the 1920s amounted to no more than $£ 1$ million a year, rising to $£ 4$ millions in the 1940 s, the figure by the mid-1960s was $£ 200$ millions. As the official Robbins Report of October 1963, which proposed this enormous expansion, explained, 'Unless higher education is rapidly reformed, [...] there is little hope of this densely populated island maintaining an adequate position in the fiercely competitive world of the future' (Robbins, 1963: para 16). Lord Robbins warned Britain's rulers, 'we are in real danger of being outclassed and undersold' (Harman et al., 1968). Robbins had estimated that there would need to be 197,000 students in universities and 75,000 in training colleges, but by October 1967 both these targets had already been exceeded. Despite the expansion, demand for college places exceeded the supply, as it became harder to gain admission. Where, in 1900, students constituted only 1 per cent of the relevant age group, by 1972 the figure was 15 percent (Harman, 1988).

\footnotetext{
9 An early, and influential document of the American student movement was written by a Berkeley University librarian, the Marxist scholar Hal Draper, under the title 'The mind of Clark Kerr' (extracts in Draper, 1965: 199-214).
} 
In France, Japan, the Scandinavian countries and elsewhere - though least where dictatorial governments feared the social consequences of university growth - the story was similar. In Mexico, student numbers expanded fast from 1960 in 73,600 to 838,000 by 1980 (Zirakzadeh, 2006).

If states had come to realise the need for large-scale expansion of university and other post-school education, they were less clear about what form these expanded institutions should take. Britain's Robbins Report recommended that big expansion should go along with maintaining the traditional relaxed and liberal ethos of university life. That did not fit well with the perceived need for universities to produce more 'trained personnel' for industry and commerce. The incoming Labour Government, from 1964, began to promote a new, cut-price version of Higher Education, in the shape of Civic Universities and Polytechnics. These, it was hoped and intended, would be more directly responsive to the needs of local business, and it was not unusual for their new Governing Boards to be appointed on this basis. ${ }^{10}$

In West Germany, the universities were re-opened after the defeat of Nazism on an essentially idealistic basis as 'a community of instructors and instructed', a place founded with the progressive, if not Utopian aim of serving 'the development of the intellect, free from material, political and ideological forces'. This created an emergent contradiction with the need to develop institutions to service capital's demand for scientific and academically-based technical progress (Budderberg, 1968). That contradiction, Budderberg suggests, evinced itself in contradictory proposals for university development. On one side, business thinkers wanted universities to become 'academic Taylorist' institutions, with shortened periods of study for individual students and stricter regimentation and standardization of courses. Such proposals to increase turnover and output hardly matched the ethos of the traditional university. ${ }^{11}$ At the other pole, Left students

\footnotetext{
${ }^{10}$ See, for example, Marvin Garsons' analysis of the Board of Regents of the University of California (Garson, 1965), or the account of the Governors of the new Warwick University (Thompson, 1968). Davidson cites a study of leading American universities: 'Altogether the evidence of major university-business connections at high levels seems overwhelming. The numerous high positions of power in industry, commerce and finance held by at least two-thirds of the governing bodies of these 30 leading universities would appear to give a decisive majority more than ample grounds for identifying their personal interests with those of business.' (Davidson, 1969:337).

${ }_{11}$ A personal memory: when I began my first academic post, in what would become Manchester Polytechnic, the Vice-Principal told new staff we should not think so much about our students as people to have their minds expanded but rather as baked beans to be processed and labeled. There is a neat reverse of this in Mario Savio's speech outside Sproul Hall in 1964: 'If this is a firm and the Board of Regents are the board of Directors [...], then the faculty are a bunch of employees and we're the raw material. But we're a bunch of raw material that doesn't mean to be made into any product, don't mean to end up being bought by some clients of the university. We're human beings.' (Harman, 1988: 38).
} 
demanded increased democratization of the universities, in the form of reduction of the universities' hierarchical structures and an increase in students' rights of self-determination and co-determination.

Robert Lumley remarks about Italy that the whole university expansion process was conducted from above, without taking student opinion into account (Lumley, 1990). The same could be said about university expansion all across the globe. Thus the expanding university sector was ripening with potential conflicts over its purpose and ethos.

In terms of their social origins, most of those who provided the rapidly growing numbers of students still came from upper- and middle-class homes, although working-class access was improving. Also, the newer universities and colleges recruited a higher proportion of women students. In terms of their social destinations, however, most students could no longer expect to join the upper class, although some could entertain such hopes. Most would become salaried employees. They might not immediately see themselves as 'workers' - though the big expansion of white-collar trade unionism suggests that many did learn to - but most could no longer expect to get beyond the fundamental insecurities and uncertainties of life as 'employees'. (Over subsequent decades, those uncertainties and insecurities would impinge more brutally on 'white-collar' sectors.)

But, while they were at university, many did not have clearly defined careers in front of them. Writing in the 1970s about the general situation of students, Callinicos and Turner suggested:

Students do not enjoy any definite relations to the productive process. While they are students, their careers remain uncertain. Their fate will be settled by imponderables like the state of the labour market and their performance in examinations. [...] Students are defined socially by their transitional situation. [...] The effect of the examination system is not to unite students into a cohesive group but to atomize them, each student's fate is settled by his or her individual performance separated from that of all the others. But they are an oppressed group... Insecurity about the future is soon reinforced by the isolation of life on the campus. Although the discipline is less rigid than at school, decisions about the content of courses, appointments, price levels or anything else remains just as remote. The corridors of power inside colleges are certainly not for the use of students, except on a few occasions and only then at the convenience of the authorities. This general alienation of students creates their readiness to rebel. (Callinicos and Turner, 1975)

It's probably useful, however, to make some further discriminations among students, in terms of the subject-areas they entered. For many, 
university education represented a period of 'apprenticeship' to a given profession or industry. The nature of the 'disciplines' they were required to study was well defined, and their education experience consisted in absorbing and mastering a fixed set of theories, facts and meanings. This was largely true in law and medicine, in engineering and business subjects, in most of economics and natural science and in most schools of psychology. Here, although university conditions of study were probably better than in most technical colleges, in both kinds of institutions the 'vocational training' function predominated. Students themselves neither expected nor were expected to develop critical views about the curriculum. Additionally, many students went not to universities but to technical colleges, often on day- or blockrelease. If these students were 'the worst victims of our educational system at every stage in its operation' (Harman et al., 1968: 24), they were also least likely to be affected by student movements, which tended to concentrate in the universities among full-time students, who possessed both the leisure and the social networks needed for debate and mobilization.

However, students in the Arts and Humanities and especially Social Science were not really 'training' for entry to specific professions, though many would expect to go into teaching, social work, various forms of administration, or work in the mass media. What they expected from their courses, and indeed were induced to expect, was some kind of nurturing of their 'critical faculties' and of their capacities for social, moral and political generalization. These were the students most likely to be searching for something akin to the classical model of the University as a liberal institution promoting freedom of thought and expression, encouraging free debate and argument - in other words, the old upper class model of a university education devoted to the relatively leisured pursuit of ideas. These students were most likely to be disappointed by the reality of university life, and - were radicalization to occur - the most likely to be responsive. They were the ones most likely to be disappointed by the reality of much of their university experience, to find their courses boring, irrelevant and alienating. Gareth Stedman Jones described their situation in 1969:

These students are formally trained to develop a creative and critical intelligence: their future occupations often demand specialized and skilled verbal or conceptual performances. But at the same time, the universities and colleges where they study impose deadeningly conformist syllabuses and systematically segregated departments of knowledge. These apprentice intellectual workers are thus riven by a constant contradiction: they must be alert and intelligent within their narrowly defined disci- 
pline, and yet be numbed and inert outside it. They must not apply the intelligence they are being urged to develop, either to the institutions where they are studying or to the society which produces them. (Jones, 1969: 32-33)

\section{While Carl Davidson cites a student from Brandeis University:}

By the time we graduate, we have been painstakingly trained in separating facts from their meaning. [...] We wonder that our classes, with few exceptions, seem irrelevant to our lives. No wonder they're so boring. Boredom is the necessary condition of any education which teaches us to manipulate the facts and suppress their meaning. (Davidson, 1969: 330) ${ }^{12}$

On the campuses, in the period before the eruption of student protest, the Left was generally weak. In the USA, McCarthyism had fatally weakened the Communist Party's position, while European Communist Parties had effectively abandoned specifically revolutionary politics in favour of parliamentarist aspirations. In some countries, there were small radical groupings. West Germany's SDS had been expelled from the Social Democratic Party, and had a perspective consisting until the mid-1960s of 'nothing much more than recruiting Marxist intellectuals, whose chief task was to be the re-establishment of a German workers' movement' (Budderberg, 1968: 27). The strongest ideological influence among them came from the ideas of Herbert Marcuse, for whom western working classes were hopelessly compromised by post-war affluence, so that any new revolutionary impulses were only likely to come from third world revolutions and marginal oppressed strata. Similar ideas also affected the emerging Students for a Democratic Society in the US, radicalised by the Civil Rights Movement but only to the stage that, in 1964, it adopted the slogan 'Half the way with LBJ'. ${ }^{3}$ The Japanese Zengakuren movement had frag-

\footnotetext{
${ }^{12}$ See also the remarks by Mario Savio on student experience at Berkeley He summarizes: 'Many of us came to college with what we later acknowledge were rather romantic expectations, perhaps mostly unexpressed at first, about what a delight and adventure learning would be. We really did have unanswered questions searching for words, though to say so sounds almost corny. But once at college we quickly lose much of the romantic vision; although, fortunately, some never give in to the disappointment. Discovering that college is really high school grown up and not significantly more challenging, many console themselves with the realization that it is not much more difficult either.' (Draper, 1965: 3-5).

${ }^{13}$ Lipset and Altbach suggest that the organized Left in the USA was quite small. They report a 1965 estimate by the left-wing National Guardian that all the various 'new left' organizations in the US together counted about 12,000 members, with a similar number of sympathizers. SDS claimed 20,000 members and supporters, out of a US student population of six million. On most campuses the organized Left was absent: a survey of Deans of Students in 849 institutions in response to
} 
mented after its efforts in 1960 to make links with striking workers had been rebuffed. The French UNEF movement was weaker than it had been since it played a very positive role in opposition to the Algerian war. ${ }^{14}$ Elsewhere tiny Marxist grouplets had small footholds in a few places.

It was in this setting that student revolt exploded across the developed Western world.

\section{Student revolt}

The first impulse towards student revolt occurred, not on a college campus, but in the 'whites only' coffee bar of a Woolworth store in Greenboro, North Carolina, in February 1960. Four Black students from the local college sat down and asked to be served coffee. Refused coffee, they continued to 'sit in' all day. Next day, more students joined them, and the next day still more. Their action set off a wave of Black student sit-ins in segregated facilities all across the Jim Crow south of the United States. For Black students over the next few years, something of the same dynamic applied that, for many Black churches, made church membership almost synonymous with belonging to the civil rights movement. McAdam cites two surveys, in 1962 and 1964, finding that respectively 39 per cent and 69 per cent of Black students were involved in the movement. 'Participation in protest activity simply came to be defined as part and parcel of one's role as a student.' (McAdam, 1982). Bearing in mind that students from schools in the Deep South tended not to be involved, that suggests rates of activism among the rest of between 60 and 80 per cent. These Black student activists got little help from their college administrations. According to one survey, only 15 per cent of the sit-in participants from public colleges reported that their administrations had been supportive. By the end of the 1960 spring term, more than a hundred students had been expelled from their colleges for

student activism in 1964-5 reported that student radicals were totally absent in 74 per cent of them. (The Left undoubtedly grew in the second half of the 1960s, but still with a minority status.) On the other hand, the same authors report another poll revealing widespread student and faculty sympathy with the civil rights movement, in which 18 percent of students described themselves as having taken part in picket lines, 'presumably mainly to enforce a civil rights objective'. That figure they found 'rather large' (Lipset and Altbach, 1967: 200-1). Mario Savio claimed that, at Berkeley, over 10 per cent of the student body had taken part directly in civil rights activity, in the South or in the Bay Area. 'These three thousand, all of whom have at least walked picket lines, are a leaven for the campus. And many more can be said to have participated vicariously: there is great and widespread interest in what those who "go South" have done and experienced' (Savio apud Draper, 1965: 3).

${ }^{14}$ UNEF membership declined from its Algerian war peak of 100,000; in 1968, despite the large growth in overall French student numbers, it had only 45-50,000 members, and was riven with internal struggles (Halliday, 1969: 317-8). 
their participation (Polletta, 2006). It seems, however, that these conservative college administrations did not provoke campus revolts.

Out of the Black students' sit-in campaign was born the Student Non-Violent Coordinating Committee (SNCC), which in turn gave a powerful new impulse to the civil rights struggle, which had been languishing after initial victories in Montgomery, Alabama in 1956. In its early years, SNCC welcomed radicalizing white students into its ranks, and it was chiefly through them that the explosion of civil rights struggles of the early 1960s fed into student politics on American campuses, and from them to the world. ${ }^{15}$ In the summer of 1964, SNCC organized a programme called 'Freedom Summer', which took quite large numbers of predominantly white middle-class students into Mississippi to help with a voter registration drive (McAdam, 1988). Mississippi racists murdered three students (one black, two white), but the general radicalizing effect on the one thousand and more who participated was profound. When they returned to their colleges in the autumn of 1964, they publicized the struggle in America's Deep South on their home campuses. Among these were Mario Savio and Jack Weinberg, who would soon be projected into new and previously unknown roles as militant campus student leaders at Berkeley.

\section{The beginning, Berkeley $1964^{16}$}

At the start of the fall term in 1964, student activists, some of whom had been involved in Freedom Summer and other civil rights activities, set up information tables on the street outside the Berkeley campus of the University of California, soliciting donations and supporters for civil rights

\footnotetext{
${ }_{15}$ Bernice Johnson Reagon (Payne, 1995) called the US civil rights movement the 'borning movement' of the 1960s, and Payne suggests that SNCC itself was 'the borning organization' of the same period. Out of it came, first, attempts at new models of activism, leadership and organization, which themselves influenced the practice and thinking of the early student movement (notably SDS), the anti-war movement, the women's movement, and others. Later in its development, SNCC also played a major part in giving birth to the idea of 'black power'. Within SNCC, too, one of the first position papers announcing the birth of 'second-wave feminism' was written. It is thus doubly possible to trace the roots of 'identity politics' within SNCC. Although never a very large organization, SNCC's history represents a critical hinge in the development of radicalism after 1960, and in that sense we are still living in its wake' (Barker and Cox, 2002). The history of SNCC's later implosion also provided a kind of 'forerunner' model of the implosions that afflicted many of the left organizations that grew out of the 1960s movements. There are fascinating reflections on the particular character of SNCC's later development in chapter 3 of Polletta, 2006; see also Polletta, 1994. On those later implosions, at least for Europe, see Harman: 1979. The idea of black power, in turn, inspired the later Black Panthers party, and movements like the Dodge Revolutionary Union Movement. For a useful introduction, see Shawki, 1990.

${ }_{16}$ There's an extensive collection of documents, photographs and other materials from the Berkeley Free Speech Movement on the web at http://www.fsm-a.org/.
} 
causes. On September 14, 1964, Dean Katherine Towle announced that, since the strip of land where the tables were set up belonged to the University, the tables were banned under existing University regulations. These prohibited advocacy of political causes or candidates, outside political speakers, recruitment of members, and fundraising by student organizations, anywhere on the university campus. The rules, she declared, would be 'strictly enforced'. There were public confrontations at the tables between the university authorities and, among others, Mario Savio and Jack Weinberg, who won audiences when they spoke in defence of free speech. On 1st October, Weinberg was arrested and placed in a police car in Sproul Plaza, inside the university area. Inspired by ideas from the civil rights movement, several thousand students sat down around the car, trapping it (and its occupants) for the next 36 hours. Speakers climbed on top of the police car to address the large crowd in a permanent public meeting. The police charges against Weinberg were eventually dropped, and he was released.

A month late, however, the university brought its own disciplinary charges against those who organized the Sproul Plaza sit-in. The Free Speech Movement, as it was now called, responded with an occupation of Sproul Hall, an administration building, The university called in the cops, and on the night of $3 \mathrm{rd}$ December some 800 students were carried from the Hall to waiting paddy-wagons. The continuing crisis in the university led to the appointment of a new acting chancellor, who introduced new rules for on-campus political activity, including the designation of the steps to Sproul Hall as an area where political tables could now be set up and speeches made. The campus movement had secured a significant victory over a conservative administration, though the issues rumbled on into the spring, involving conflicts with the University of California as a whole, and its Regents. ${ }^{17}$

\footnotetext{
17 The Regents commissioned a report into the causes of the unrest at Berkeley, which was scathing about the university administration: 'The University [...] displayed a consistent tendency to disorder its own principles and values. While dedicated to the maintenance of a house for ideas and thought, it proved selective in determining whose ideas would gain admittance. While upholding the value of a continuing discourse in the academic community, it refused to engage in simple conversation with the membership of that community. While positioned as the defender of man's right to reason, it acted out of fear that a volatile public would react against the University if exposed to the reasonings of students. While championing the value of the individual and his responsibility for his own person, it had sought to prevent the individual from suffering the consequences of his own self-determined actions in society. While postured to avoid prejudgment of the facts, it sought to determine before the fact the legality or illegality of actions students would plan to take in the surrounding community. While responsible to and for itself, the University assumed it would be charged with responsibility for others, and in fear that the assumption would prove valid, established rules prohibiting others form acting on their own responsibility' (The Byrne Report, cited in Draper, 1965: 237).
} 
Heirich comments that there seemed to be a 'kaleidoscope of crises', involving seven more collective confrontations in the spring of 1965, in whose course the targets and foci of conflict kept shifting.

With each shift in the focus of conflict, issues became more difficult to meet directly and to resolve - both because they were more general and because they came closer to the heart of genuine value dilemmas that higher education had failed to solve in its massive growth over the preceding twenty-five years. (Heirich, 1970; Weinberg, 1965)

At each stage, different levels of authority in the university were challenged: from the student affairs staff to the deans, and then to the president and chancellor and then to the Regents. When the state Governor intervened, he was challenged by a university-wide strike. At each stage, the involvement of further authorities meant that a wider range of university relationships came into question, and under the students' critical surveillance. Weinberg points out that the civil rights campaign tables were not just aimed at racism in the Deep South, but at the practices and interests of powerful local employers in the Bay Area. Those interests, he suggests, pressured the university, which succumbed. In that sense,

many conclude that the FSM is an extension of the civil rights movement... The University of California is a microcosm in which all of the problems of our society are reflected. Not only did the pressure to crack down on free speech at Cal come from the outside power structure, but most of the failings of the university are either on-campus manifestations of broader American social problems or are imposed upon the university by outside pressures. (Weinberg, 1965).

\section{Draper comments on the whole process:}

One of the most unique features of the Berkeley student revolt is that from its beginning to its climax it was linked closely to the social and political issues and forces of the bigger society outside the campus. At every step the threads ran plainly to every facet of the social system: there were overt roles played by big business, politicians, government leaders, labor, the press, etc., as well as the Academy itself. This was no conflict in the cloister. (Draper, 1965)

The broadening of the conflicts meant that the nature of the university as an institution came increasingly into question, along with its linkages to the national and state-wide power structure. All of this tended to radicalize sections of the student body. 
The very title of the movement, the Free Speech Movement, indicates the initial battle-ground between university authorities and students. Similar issues would resonate through later campus movements too. As an issue, 'freedom of speech' possessed a large mobilizing capacity. Previous civil rights activity, both in the Deep South but also in the San Francisco Bay area, had already habituated quite large numbers of Berkeley students to organized collective action. ${ }^{18}$ The protest at Berkeley was not simply led by 'radicals', but by a coalition that included quite diverse political forces: civil rights campaigners, radical, socialist and peace groups, but also the Young Democrats and all three Republican Clubs including the right-wing Youth for Goldwater (Draper, 1965:31-2) ${ }^{19}$ There was something seemingly 'nonideological' about the student demands, which accounts in part for the very explosiveness of the student uprising: 'This was the explosiveness of uncalculated indignation, not the slow boil of planned revolt [...] the first discovery of the chasm between the rhetoric of Ideals and the cynicism of Power among the pillars of society' (Draper, apud Harman, 1988: 44). On the other hand, the very fact that the coalition was so broad meant that it could, and did, easily fracture and disassemble almost as quickly as it was formed. Nonetheless, what Berkeley showed was that an initially small group of students could, faced with a university administration that lumbered into action almost unaware of the sleeping energies its own responses could provoke, convert relatively small oppositional forces on a campus into a broad and wide-ranging student movement. If such movements lacked much by way of overall 'staying power', they were nonetheless, in the 1960s, an entirely novel development. ${ }^{20}$ They also provided a kind of political 'forcing house' in which numbers of the student participants became, through their experiences within the movement and the exposure this gave them to

\footnotetext{
${ }^{18}$ In March 1964, more than nine hundred people had been arrested during demonstrations at the Sheraton-Palace Hotel in San Francisco, including some two hundred from Berkeley (Heirich, 1970: 45). According to one study, more than half of those who sat down round the police car in Berkeley plaza had taken part in at least one civil rights protest, and 17 per cent had participated in seven or more (Lipset and Altbach, 1967:202). Savio claimed that over 10 per cent of the Berkeley student body had taken part directly in civil rights activity, in the South or in the Bay Area (Draper, 1965: 3).

19 At the London School of Economics in 1967, the motion to occupy the college premises was moved by the former chair of the Conservative Society (Harman, 1988: 43).

${ }^{20}$ Two American academics noted: 'Recent events in American student political life have shown that it is possible to remove students from their liberal but generally apathetic tendencies during a crisis. When the chips are down, as they were in Berkeley, a large proportion of the students supported the militants of the Free Speech Movement, even though the overwhelming majority did not normally take part in politics and have not remained active in the student movement. Similarly, such students will back a movement for civil rights in the campus community.' (Lipset and Altbach, 1967: 237-8)
} 
radical critiques of existing society, much more ready to engage in wider radical politics.

Hal Draper, himself a librarian at Berkeley, was one of the few ideologically formed socialists in the faculty who supported the students from the beginning. His critique of Clark Kerr's ideas was very influential among the students who played a leading part in the early stages of the Berkeley movement. ${ }^{21}$ In the book he published in 1965, he attempted a political anatomy of the newly emerged generation of student radicals. If they were not, as he put it, 'finished radicals', they had identified themselves as radical rather than liberal. Still in the early stages of a process of radicalization, they tended to concentrate on the 'issues' and to be more certain what they were against than what they were for. Among them '[...] the reservoir of radical energies is greater than the stream of radical beliefs'. Their overt thinking was marked by a conscious avoidance of any particular radical ideology. Disinclined to generalize and systematize their positions, they preferred to be 'pragmatic', inclining to substitute a 'moral' approach for political and social analysis. ${ }^{22} \mathrm{He}$ may well have had in mind a leading figure like Mario Savio, whose speech to students as they prepared to occupy Sproul Hall was reproduced all over the USA:

There's a time when the operation of the machine becomes so odious, makes you so sick at heart, that you can't take part, you can't even passively take part, and you've got to put your bodies upon the gears and upon the wheels, upon the levers, upon all the apparatus, and you've got to make it stop! And you've got to indicate to the people who run it, to the people who own it, that unless you're free, the machine will be prevented from working at all! (cited in http://en.wikipedia.org/ wiki/Mario_Savio)

Draper cited several reasons for the Berkeley students' rejection of 'ideology': they were rejecting old ideologies, not yet having met any new ideology that might carry them away; they feared ideological clarity might threaten the unity of their movement; and the general political climate of mid-1960s America made them refuse labels like 'socialist'. Their position had some advantages, in that it was harder to smear them with being 'communists'. The very unformed character of their ideas contributed to the

\footnotetext{
${ }^{21}$ Draper was the second speaker from the roof of the police car in Sproul Plaza, after Mario Savio.

${ }^{22}$ Heirich has some materials from student essays about why they decided to join the FSM. They mix together moral arguments and beliefs, tactical commitments, a sense that the movement had generalized beyond a few radicals behind tables, expectations of success, and having friends who were participating (Heirich, 1970: 180-1).
} 
explosiveness of their movements, indeed they lacked the kind of 'theoretical wisdom' that told them they couldn't win: a degree of naiveté and inexperience were as 'shield and buckler' to the student movement. At the same time, ideological weaknesses meant that they were ill-equipped to answer questions about what to do next after mass mobilizations had been achieved. Such movements could be tamed quite easily if the authorities recovered their poise and offered compromises that would quieten things down. They were liable to lack persistency in struggle, so the movements could rise and fade away with equal facility. 'The simple/moral drive to action' is more ephemeral than the ideological.' (Draper, 1965: 156-166).

If Draper was at one immensely enthusiastic, and sceptical, about the potential of movements like those at Berkeley, he was analyzing a situation in statu nascendi, not knowing how it might develop. ${ }^{23}$ In the event, the Berkeley events did not immediately set off a rash of campus challenges to university authorities. In the United States, at least, other forms of student politics began to gain momentum. The American war in Vietnam slowly emerged as a core issue. Initially, the anti-war movement was tiny, but it grew through the new device of 'teach-ins' on many campuses, beginning at Ann Arbor, Michigan in 1965. The teach-ins provided Marxists with an audience they'd not enjoyed for many years: audiences of thousands listened to Isaac Deutscher in Washington and to Hal Draper at Berkeley, as they debated with government spokespeople and largely won the arguments. Later that year the anti-war demonstrations started to gain serious momentum (Harman, 1988: 72). In turn, they fed back into campus radicalism, not only in the US, but in Europe.

\section{The movement spreads}

At Berlin's Free University, a student movement erupted in spring 1965 over free speech issues when the Rector banned a speaker invited by students to address them on the 20th anniversary of the Nazi defeat, and again when the university sacked an Assistent for criticizing the Rector in a letter to a Berlin newspaper (Boren, 2001; Seabury, 1967). Later that year, a University Senate ruling, that no university facilities could be used for political activities, set off a second student insurgency. Thousands of students took part in street demonstrations and strikes, with thousands more signing petitions calling for reform of the administration.

\footnotetext{
${ }^{23}$ Draper was to offer his own views about left strategy, arguing that the movement, to make lasting gains and develop ideological clarity, should 'lay new track' - to the American working class (Johnson, 1997).
} 
The socialist student organization, the SDS, played the leading part in these and subsequent demonstrations. Originally the SDP's student section, they had been expelled in 1960. Strongly influenced by the ideas of Marcuse, the SDS focused attention on anti-imperialist politics, notably against American policy in Vietnam and the Middle East. When Hubert Humphrey visited Berlin in 1967, they organized predominantly student demonstrations against his presence, and in June that year, on a larger scale, they mobilized demonstrations against the visit of the Shah of Iran. Police surrounded and violently attacked a student demonstration outside the Opera House, clubbing both demonstrators and bystanders. One student, Benno Ohnesorg, was kicked unconscious; as his unconscious body was dragged to a police wagon, an officer placed a gun to his head and shot him. Tens of thousands attended his memorial service, which became a huge protest for university and political reform, compelling the resignations of the Police Chief and SDP Mayor of West Berlin. As in Italy, the tendency of the police in Germany to respond with brutal violence to student protests conditioned the form that radicalization took (Della Porta, 1995; 1996).

The SDS provided a basis for the emergence of an 'Extra-Parliamentary Movement' (APO), whose immediate triggers were Germany's support for the Vietnam war and the emergency legislation which was linked to increasing repression of protestors. Budderberg (1968: 29) suggests that the demonstrations against the American war in Vietnam were especially significant in West Germany, in that they broke the long double taboo of anti-communism and opposition to the Americans (who contributed to Germany's liberation from the Nazis, and maintained the 'freedom' of West Berlin). These and other student demonstrations shifted opinion in Germany. Where a poll of young people in spring 1967 had concluded that "young people have very little ideology [...]. They have only one ideology, "success"', another poll in January 1968 showed 67 per cent of young people approving of the student demonstrations (Harman, 1988: 53). This kind of opinionshift accompanied rabid attacks on student radicals in the right-wing press empire of Axel Springer. Radical students certainly held the Springer press responsible for the serious wounding of the German student leader, Rudi Dutschke, by a right-wing would-be assassin who shot him in Berlin in April 1968. This event, in turn, set off a round of student attacks on the offices and distributors of Springer newspapers. The German student movement peaked in April and May of 1968, as the anti-Springer demonstrations were rapidly followed by May Day demonstrations against the military dictatorship in Greece, strikes in almost all the German universities against emergency laws introduced by the CDU-SDP 'Grand Coalition' government on 
15-16 May, and a day of protest against Germany's neo-Nazis on 18 May. In street battles across the country, two more protestors were killed.

After the summer of 1968, the APO rapidly fragmented. The passage of the emergency powers legislation drove some to cynicism and personalistic withdrawal. After its spring 1968 peak, SDS fell apart at its congress later that year. German radicalism was marked by two new developments. On one hand, there was the rise of the 'Spontis', sub-cultures involving partial withdrawal from political engagement, lifestyle responses in place of socialist and communist student politics. The growth of the 'Spontis' saw a turn to co-ops, bio-bakeries, alternative culture, and squatting. On the other hand, a small section of the German movement turned, despairing of mass protests, to individual and small-group terrorism (Zirakzadeh, 2006).

One thing that marked the German student movement was its almost total disconnection from the workers' movement. Germany's labour movement in the postwar decades was among the least strike-prone in Europe. Most radical students readily accepted the arguments of writers like Marcuse and Fanon that the working class was no longer capable of acting as a revolutionary subject, being co-opted and ideologically blinkered by commodity consumption. They looked instead to 'non-commodified' alternative revolutionary subjects: to students themselves as a 'revolutionary class', to outsiders like prisoners and the chronically unemployed, and to third world peasants and 'lumpen-proletarians'. Budderberg refers to the 'guerrilla-cult' among German students, along with their Mao badges and Guevara posters. They also drew on the analyses of fascism produced within the Frankfurt School. These treated the present bourgeois capitalist system as 'closed' and 'without the possibility of a concrete negation', thanks to the 'authoritarian character structure' that consumerism and the media produced among workers (Budderberg, 1968: 31). Their isolation from working-class support made the German student movement very self-dependent, also encouraging a certain elitism towards the rest of society. It was one of the first student movements to decline and fade.

In France and Italy, and to a degree in Britain, by contrast, the story was somewhat different. In these three countries, in different ways, active intersections between student and workers' movements produced distinctive outcomes.

In France, the years 1965-68 witnessed a significant growth of workingclass militancy (Cliff and Birchall, 1968), partly manifested in a rising level of local strikes but also in larger, if symbolic strikes called by the largest union federation, the Communist Party-led CGT. There was no sense, however, of a major crisis brewing. By comparison with their colleagues in 
Germany or Italy, French students seemed more docile. When, at Easter 1968, news came in of the attempted assassination of Rudi Dutschke in Berlin, French far left students called a demonstration in Paris. It mobilized at most 200 students, and promptly dispersed when the police appeared. ${ }^{24}$ On the outskirts of Paris, at the Nanterre university campus, however, a little trouble was brewing. There, a small anarchist group raised demands about Vietnam on the one hand, and sexual liberation on the other. Their agitation bore fruit, not so much because of student political acuity as because of the authorities' lack of it. Daniel Cohn-Bendit and others from the Nanterre students were summoned to the Sorbonne to answer charges, shifting the conflict from the suburbs to the city centre. When Sorbonne students demonstrated in support of the Nanterre students, the university called in the police, who attacked the students, further raising the temperature, and drawing in larger student numbers. On 3 May, the authorities decided to close the Sorbonne, no doubt hoping that approaching examinations would turn most students to their studies. The miscalculation was immense: for a week there were daily student demonstrations and clashes with the police, who used batons and CS gas.

The climax came on the night of Friday 10 May, when students defending themselves in the Latin Quarter began building barricades. All night 30,000 of them fought the hated CRS riot police, swinging public sympathy towards them. Next day, faced with a decision of the CGT to call a one-day national strike in solidarity with the students, the prime minister, Pompidou, announced the immediate re-opening of the Sorbonne and indicated that imprisoned students would be released. But it was too little and too late. The initiative passed from the government.

Monday 13 March saw a very large - perhaps a million-strong - demonstration in Paris, with participants waving handkerchiefs and chanting 'Adieu De Gaulle' with great merriment. The Communist Party deployed large numbers of its cadre to act as stewards, chiefly to keep the ('ultra-left') students apart from the workers' contingents. The same day, students occupied the main buildings of the re-opened Sorbonne.

The CGT leaders had clearly intended that, in line with previous practice, the one-day strike would provide an opportunity to demonstrate their continued strength, and to allow workers to 'let off steam' in the demonstration. And there things might have ended, with the students occupying the

${ }^{24}$ I was there. Afterwards, a student member of the Socialisme ou Barbarie group moaned to me about the 'a-political and cowardly' character of French students, declaring that he would like to move to Britain, where at least there was a lively anti-Vietnam movement. This was six weeks before the 'May events'. 
Sorbonne for a while and finally fading away. But on Tuesday, workers at the Sud-Aviation aircraft factory at Nantes on the Atlantic coast occupied their plant and locked up the management in their offices. Initially this attracted little attention, but within days similar occupations were launched in workplaces up and down France. The strike movement was set in motion by local groups of militant activists, without reference to the leaders of the union federations. Initially taken aback by these developments, the union leaderships stepped in to encourage a movement they had not initiated, so as not to lose control. Within two weeks, more than nine million workers were on strike, across every sector of society, in the largest single general strike Europe had ever experienced. During the strike, while there were some notable and interesting examples of workers extending control over the production and distribution processes, only in a few occupied workplaces was the strike run by a democratically elected strike committee, More often unions imposed strike committees which commonly did not involve the mass of strikers in much decision or action (Birchall, 1987).

Left-wing students tried to forge links with striking workers. When they succeeded, the results could be dramatic. One memoir by a Renault worker recalls:

In the first few days of May every evening I took five or six workers - quite often members of the Communist Party - in my car to the Sorbonne. When they returned to work next day they were completely changed people. Through the students and the 'groupuscules' they got the political education they did not get from the CP. There was a completely libertarian atmosphere at the university, so different from the totalitarian atmosphere at the factory. The student demonstration created an environment in which people were free to coin their own slogans. In the official trade union demonstrations, only certain, centrally determined, slogans were permitted. When Renault was occupied, the workers experienced a change from control by the management which uses modern manipulative techniques, to control by the $\mathrm{CP}$ bureaucracy, which is completely totalitarian. In Renault their freedom was alienated. In the Sorbonne they felt free. When a worker went to the Sorbonne he was recognized as a hero. Within Renault he was only a thing. In the university he became a man. This atmosphere of freedom in the sense of being human gave great combativity to the young workers. (cited in Birchall, 1987:21)

Fearing more of this kind of 'contagion', the CP and CGT worked hard to keep students and workers apart. When a large student demonstration marched from the Sorbonne to the Renault factory at Billancourt, to show solidarity with the occupying workers, the factory gates were shut tight against them - by the strike committee. 
While the student movement could provide much of the 'colour' of the May events, it could not shape developments in the general strike movement. Even though perhaps a third of the strikers actually belonged to one of the three trade-union confederations, those bodies nonetheless maintained a grip over the progress of the strike. There was no significant rank-and-file movement 'from below', based on the striking workplaces themselves, and capable of defining the forms of organization and goals of the strike movement. Thus, from late May onwards, the union leaders - and especially the CGT - were able to organize a return to work on the basis of pay increases negotiated in the Grenelle agreements with the employers this despite serious expressions of dissatisfaction even in CGT strongholds like Renault Billancourt. The movement which, at some points, appeared to herald a veritable social revolution, thus ended quite tamely. The return to work also greatly reduced the impetus of the student movement. After May-June 1968, although there was some increase in the membership and audiences of the left-wing 'groupuscules', the French student movement did not again achieve any great prominence.

That said, the imaginations of students across Europe and beyond were entranced by the example of the French students, who had seemingly been able to 'detonate' a full-scale social crisis involving millions of workers. The 'May events' contributed, internationally, to a widespread revival of interest in revolutionary socialist ideas. If the movements of the 1960s had a 'peak', it was surely reached in France.

Yet it was probably in Italy that the idea of student-worker alliances was taken furthest, even if nothing quite like 'the French May' occurred there. As Ginsborg suggests, '[ $t$ ] he Italian protest movement was the most profound and long-lasting in Europe. It spread from the schools and universities into the factories, and then out again into society as a whole' (Ginsborg, 1990: 298). Lumley refers, not inaptly, to the 'organic crisis' in Italy 1968-9 (Lumley, 1990: 9, 47).

The Italian student movement found its initial basis in material demands. There had been a big expansion in student numbers, without a concomitant growth in facilities. Where in 192340,000 students were served by 2,000 lecturers, by 1967 there were 450,000 students but only 3,000 lecturers (Harman, 1988: 138). Teaching was poor, and matched by book and library shortages, so that only 25-30 per cent of students succeeded in completing their studies. One of the first campus movements developed in 1967 among architecture students at the Polytechnic in Milan, where generalised criticism of government planning went hand in hand with a critique of the form of education on offer. The students occupied their college for 55 days 
(Lumley, 1990). At the Catholic University of Trento, during the autumn of 1967, students attempted to formulate a Marxist analysis of students' role in society. Students at the even more Catholic University at Milan followed them with a struggle, initially over fees, that rapidly sought to generalise. At Milan, the Rector called in the police, provoking among students 'indignation, suffering and deeply troubled Christian feelings in the face of the authorities' behaviour' (Ginsborg, 1990: 303). As Lumley (1990: 80) remarks, had the rector not called the cops, it seems likely this mobilization would have fizzled out, especially since at that time (mid-November 1967) there was no national student movement. But the Rector at Milan, like university heads across the world in this period, took it for granted that 'authoritative' measures were needed to 'restore order': without such authorities, could there ever have been student movements? Milan was followed by Turin, where students rejected the Education Minister's proposals for university reform: these suggested cuts in student numbers and the introduction of a hierarchy of courses and of students. Here, for the first time in Italy, teaching, course content and the examination system came under their first concerted student attack. Over the winter, most Italian universities joined the fray, along with some secondary schools. In January 1968 alone, 36 universities were occupied (Lumley, 1990: 66). At Turin and Trento, students began interrupting lectures to ask professors questions arising from the issues debated in student assemblies. The professoriat indignantly turned against the students, providing few sympathisers for their movement (Ginsborg, 1990: 303). A further turning point was reached in Rome in February, where students were involved in pitched battles with the police.

From the start of 1968, the university movement spread to high schools, including the coordination of strikes through Milan's upper secondary schools. Most high-school teachers were unsympathetic to the students' critique of pattern of education; indeed 'it took the student movement to create a generation of teachers committed to more democratic and egalitarian methods' (Lumley, 1990: 94-98).

The whole Italian movement was marked by a strong anti-authoritarian character, with students' developing critique of society extending to the nuclear family and the traditional parties of the Left. Here too, although the Italian student movement was 'less theoretical' than in Germany, Marcuse's ideas were influential. ${ }^{25}$ The movement provoked a 'moral panic',

${ }^{25}$ Marcuse's One-Dimensional Man sold 150,000 copies within a year of its publication in 1967 (Lumley, 1990: 122). 
not only in conservative circles but also in the ranks of the Communist Party. In the wake of the Rome battles, the film-maker, Pier Paolo Pasolini, published a poem attacking the students from the side of the policemen he described as 'true proletarians' (Ginsborg, 1990: 307; Lumley, 1990: 74). ${ }^{26}$

After the spring of 1968 , however, campus issues faded away. Unlike German students, the idea never caught hold among Italian students that they were 'the revolutionary class'. One participant recalled that 'after the struggles of ' 68 a large number of students were no longer interested in the university $[\ldots]$ it was no longer where they socialized and its struggles appeared to them to be futile and folkloristic' (Lumley, 1990: 112). They turned, rather, towards the factories. In March 1968, a strike and demonstration over pensions drew support on a much bigger scale than had been expected. Then, in May, news of the thrilling events in France raised the level of confidence and excitement, impelling militant students towards working-class struggle.

This turn coincided with a sharp shift in the forms of student organization. Where the campus struggles had involved mass student assemblies and forms of 'participatory democracy', students now rushed to build what they saw as 'Leninist' organizations. If France had proved the need to build a revolutionary alternative to the Communist Party, that project required organization, ideology, discipline and revolutionary strategy. Drawing on a mixture of partly mythologized third world revolutionary movements, students combined ideas taken from 'guerrilla foci' and Chinese and Vietnamese party structures. ${ }^{27}$ One Milan student document declared: 'only the working class can make the revolution, but whilst capital has its police [...] the student movement is the guerrilla force of the working class in as far as it creates disorganization and disorder'. Students identified themselves less as students, and rather in various ways as detonators, ideologues, leaders, and guerrillas. 'After the dramatic events at Fiat during the industrial dispute of June-July 1969 when mass meetings involved thousands of workers and students, it seemed that the overthrow of capitalism was a real possibility'

\footnotetext{
${ }^{26}$ In early May 1968 the Communist Party Secretary issued a self-critical article admitting errors in party policy towards students and speaking of a 'certain erosion in the internal life of the Party' (Halliday, 1969: 306).

${ }^{27}$ Lumley comments on the Italian student Left, 'The particular predilection for myths is clearly manifested in their fascination for China. China acted as a sort of spiritual homeland for a generation which could no longer believe in the USSR. Much of the young Italian intelligentsia of the period greatly admired the Chinese Cultural Revolution. China represented a model of how intellectuals could work with and among the people. [...] At the same time, Chinese culture was presented as the combination of popular wisdom and a sophisticated but simple Marxism. [...] Above all, there was an image of Chinese people as hard-working but happy. [...]' (Lumley, 1990: 127-8).
} 
(Lumley, 1990: 114). There rapidly emerged a number of competing groups, together making up the largest revolutionary left in Europe, but one that was ferociously divided, incapable of unity in action, and prone to (male) leader cults. Believing that revolution was just around the corner, these groups were not well adapted to understanding the roots of reformism in unions and parties, and outside the younger semi-skilled workers in the big factories of the North.

In time, these features would reveal major weaknesses. But in the immediate situation, between the autumns of 1968 and 1969, 'the groups lived a magical moment, as significant numbers of workers were attracted to their ideas' (Ginsborg, 1990: 313). The scale of industrial conflict during the Hot Autumn of 1969 gave Italy the third largest strike movement recorded in history in terms of lost working time, exceeded only by 1968 in France and 1926 in Britain. Additionally, Italian workers went further than either British or French in the challenges they issued to the organization of work and authority in the factory. For a period, the unions lost the initiative to rank and file committees in the factories. Workers put forward new demands, including reductions in differentials, better control over safety and conditions, a breach in the link between wages and productivity. And they did this using new forms of struggle, involving mass assemblies as means of decision-making, and a plethora of wildcat strike forms (Regalia, Regini and Reyneri, 1978; Tarrow, 1989a). ${ }^{28}$ The temperature of the time was illustrated by the chant on a demonstration of Fiat workers and students: 'What do we want? Everything!'

If the union leaders took longer to recoup their position than their French colleagues the previous year, they nonetheless proved able to adapt to changing conditions and 'ride the tiger' of worker militancy - partly by relaxing party control over themselves. They won major concessions from employers in the autumn of 1969. As it turned out, the outcome of 'the "hot autumn" $[. .$.$] was not a further development of the revolutionary trend of$ the previous year, but rather the reassertion of trade union leadership in

\footnotetext{
${ }^{28}$ Tarrow catches something of the atmosphere: 'The extension of the strike to the plant level was more than quantitative; it reflected a flowering of new strike forms, some inherited from past cycles of industrial conflict, but others invented on the spot. [...] A whole new vocabulary of strike forms rapidly developed, from the sciopero bianco (go-slow), to the sciopero a singbiozzo (literally, hiccup strikes) to the sciopero a scacchiera (chessboard strikes) to the corteo interno (marches around the factory grounds to carry along undecided workers) to the presidio al cancello (blocking factory gates to prevent goods from entering or leaving the plant).' These varied forms of strike were combined with different forms of collective action, both within and outside the plant. They often 'contained symbolic military elements' but also 'important elements of play and theatre and bore a resemblance to the traditional carnival' (Tarrow, 1993: 296).
} 
the factories' (Ginsborg, 1990: 318). Lumley concurs: '[...] during the Hot Autumn the unions recouped some of the prestige they had lost in previous months. This enabled them to monopolize negotiations over the contracts and to re-establish control over shopfloor organization'. The new contract signed at the end of 1969 was generally seen as a major victory for the workers, and a defeat for the bosses, but 'its effects on the social movement, which had seen a good contract as a common goal likely to benefit all workers, were complex' (Lumley, 1990: 243, 249). It undermined and reined in mobilization, as workers hoped to recoup money lost during the stoppages. On the other hand, it had nothing like the demobilizing effect of the Grenelle agreements in France in '68. Conflicts continued over contract implementation, with mass action still seen as the most effective way to make gains: there were 4,000 strikes in 1970. Nevertheless, after 1969 there was not the same élan and sense of unity between workers and revolutionary students.

In the factories, a new system of factory councils provided more workplace control over union policy, and union membership grew by more than half between 1968 and 1975. But the period 1971-3 was one of deepening economic crisis, and union policy shifted from attack to defence. After 1973, as the economic crisis worsened, the balance of workplace power shifted back towards the employers and factory councils declined in importance.

The years after 1968 also saw a flourishing of other movements in Italy. The dominant models of revolutionary left organization were ill-adjusted to these new developments, especially to the growth of the women's movement. This period also saw a small section of the Italian left turn towards the terrorism of the Brigata Rossi, a response of elitist impatience. Ginsborg (1990: 340-342) suggests some reasons why the left's revolutionary aspirations failed. They suffered from their sectarianism, and their domination by models drawn from Third World national liberation movements, but above all from the weaknesses of their understanding of their own society. Too much focused on the large factories of the North, and prone to exaggerate immediate revolutionary prospects and to underestimate the popular roots of reformism, they could displace the old 1960s student organizations but not so easily the Italian Communist Party or the union leaderships. What Ginsborg doesn't explore, however, is how a more realistically rooted revolutionary politics might have fared. With better politics, the later implosion of the revolutionary groups in the later 1970s might have been avoided.

In Britain, the student movement was initiated at the London School of Economics, where students occupied in protest at the appointment as college head of Walter Adams, formerly an ally of the racist regime in 
Rhodesia. Radicalization was slower here than in Italy: the first student banner read 'Down with the pedagogic gerontocracy' and it was two years before the cry became 'Free free the LSE, free it from the bourgeoisie' (Harman, 1988: 45). Like the Berkeley movement, the LSE struggle initially seemed to be an isolated occurrence, and did not immediately set off struggles elsewhere. The growth of the movement against the Vietnam War, and the impulses flowing from the May events in France, provided the major impetus. Occupations at Hull University and the Hornsey College of Art were more in the nature of challenges to the system itself than local-issue campaigns. 1969 saw a big growth in campus revolts, in which issues to do with university 'files' came to the fore. At Warwick University, occupying students discovered that the university was collaborating with local employers in spying on both students and faculty members, and in refusing applications from would-be students on political ground. At Birmingham, files from Warwick were published, revealing intolerable racist conditions imposed on work in the new teaching hospital in Salisbury, Rhodesia by the Smith regime: these led Birmingham University Senate to phase out its links with University College, Rhodesia (Thompson, 1970). At Leeds, students discovered that college porters were being ordered to pry into student political activities in the student halls, uncovering a history of spying on lecturers and students by the secret services. Many of the student struggles in Britain conformed to the picture drawn by two American commentators:

Student political rebellion tends to break out when a series of events which violate the liberal bureaucracy's norms set off shocks among those students who have not yet been sufficiently assimilated into the corporative system. The university administration is the de facto ruler of academia. It not only has the power to move against student dissidents; it is also often able to use the weapon of time to its advantage. It can forbid, harass, abolish and destroy student institutions and activities; and it can do so just prior to the final exam when students are away from the campus or between semesters. Nevertheless, the administrators are sometimes forced to drop their liberal façade. When their informal mechanisms of control give way to vulgar manipulation and repression a critical stage is reached. Expansion along these lines by university elites moves students to act to protect their rights. (James Jacobs and James Petras, cit Harman et al., 1968: 54)

The quite common pattern, seen equally in Berkeley, in Berlin or in Paris, involved a quite small minority of radical or revolutionary students seizing the opportunity provided when college administrations turned to authoritarian measures to contain or crush incipient student rebellions, and managing 
to rally much larger numbers of students behind them around essentially 'liberal' demands about freedom of speech and the like. Thus 3,000 students at Manchester University occupied the administration buildings in 1969 after the Vice-Chancellor secured an injunction forbidding three named officers of the student Socialist Society from addressing a students' union meeting. ${ }^{29}$

However, if a large part of the student body was willing to take collective action in defence of liberal rights, not all of them were in any meaningful sense 'radical'. When the immediate struggle was over, most returned to their studies and careers. At the same time, a minority was quite often 'radicalized' by the experience of collective action, and it was this minority that was open to joining actual radical and socialist groupings. In the excitement of the rapid expansion of student movements, this was often ignored or forgotten. Some left-wing thinkers, in Britain and elsewhere linked to the Fourth International and to the journal New Left Review, elaborated a political theory in this period according to which the universities would become 'red bases' from which more general assaults on the capitalist system might be launched. Ernest Mandel of the FI declared 'the university can be the cradle of a real revolution' (Callinicos and Simon, 1975: 122). Alain Geismar in France declared, 'We want to make the university into a bastion from which we can pursue the struggle against capitalism' (Halliday, 1969). In line with this, Alexander Cockburn offered a strategy in which 'the emergent student revolutionaries aim to turn the tables on the system, by using its universities and colleges as base areas from which to undermine other key institutions of the social order' (Cockburn, 1969). The strategic proposal rested on an analogy, almost by association, with Maoist and Guevarist notions of 'bases' and 'foci'. James Wilcox argued: 'The guerrilla's liberated zone is initially located in those areas which are geographically inaccessible to the repressive forces of the established order. We must ask ourselves whether the complex structures of late capitalism do not contain areas sociologically inaccessible to the repressive forces of the ruling class' (Barnett, 1969; Fernbach, 1969; Triesman, 1969; Wilcox, 1969). ${ }^{30}$ Fred Halliday saw student power on the campus (with joint control with academics) as an attainable goal: 'There is no doubt about the practical and political feasibility of liberated institutions of higher education, acting as base areas for general revolutionary struggle' (Halliday, 1969). Robin

${ }_{29}$ The Manchester administration looked especially foolish when it turned out they had the wrong names, relying on the previous year's society list!

${ }^{30}$ The students of Athens Polytechnic, whose gates were smashed down by Papadopoulos's tanks in 1973, put that inept proposition to the ultimate test. 
Blackburn put out a leaflet to the LSE Socialist Society declaring, in rhetoric that might have been borrowed from the Communist Party's 'Third Period', '[...] those who reject the strategy of the Red Bases and the tactic of the New Year offensive will be in serious danger of becoming the objective allies of social imperialism and social fascism' (cited Callinicos and Simon, 1975: 12). The key problem with the 'red bases' notion was its failure to take account of the impermanence and inner contradictions of the 'bases' themselves. Generalities about a 'new student vanguard' ignored the vast numbers of students who remained untouched by the new militancy, and the episodic attachment even of many of those who did briefly join campus struggles. ${ }^{31}$

In British workplaces, the 1960s witnessed an almost continuous rise in the numbers of small-scale, local 'unofficial' strikes, many of them, in conditions of full employment, so short they did not reach the notice of the official statisticians (Cliff and Barker, 1966; Donovan, 1968). The strikes were called and led by shop stewards rather than paid trade-union officials, and commonly concerned not just pay but local challenges to managerial power. Although uncoordinated, an official inquiry declared there was 'anarchy' on the shopfloor in British industry (Donovan, 1968). Moves, first by the Labour Government (to 1970) and then by the Tories (1970-74) to 'regulate' industrial relations shifted the form of strikes: while the number of 'unofficial' strikes declined, they were replaced by large, semi-politicized strikes and national demonstrations against anti-union and pay-control legislation. Two struggles especially defined the period. In 1972, the miners broke the pay freeze with a massively effective strike, and the London dockers broke the Industrial Relations Act. In both strikes, solidarity action by other workers played a crucial part (Darlington and Lyddon, 2001). For left-wing students the chief focus was now not Vietnam but solidarity with workers' struggles. Talk of 'red bases' faded away. In early 1974, in face of continued union challenges, the Tories called a general election on the theme 'who governs?' and lost to Labour.

Note should also be made of a few other countries in which student rebellions occurred, with very mixed results. In Eastern Europe, in March 1968, Warsaw university students were involved in significant protests against the 'communist' regime. Their movement was crushed, with a few of their academic sympathizers losing their jobs. The Polish student movement in 1968

\footnotetext{
${ }^{31}$ There were 'new left' commentators who did recognize this: see for example Davidson, 1969. Davidson also had a better sense than some excited commentators about how student consciousness develops, and about the need for radicals to be respectful towards the majority and their struggles, rather than just denouncing them as 'backward'.
} 
met with no answering echo from the workers. When, two years later, the coastal workers in Gdansk and Szczecin revolted against the regime, in struggles that included a massacre of workers at the Paris Commune shipyard and the first formation of Inter-Factory Strike Committees, the workers in their turn fought alone (Baluka and Barker, 1977; Laba, 1991). Not until 1980, with the emergence of the Polish 'Solidarity' movement, did workers, intellectuals and students found common cause. In 1980, however, it was the workers who 'detonated' the struggle, with students organizing on Poland's campuses in the wake of the workers' extraordinary victories (Barker, 1986; Goodwyn, 1991).

In Yugoslavia in 1968, Tito deflated the student movement by addressing the nation and declaring his support for the students' action programme. Only after the movement had subsided, some weeks later, did the regime close the centre of agitation, Belgrade's famous Philosophy and Sociology Faculty, and take disciplinary action against its leaders. Tito had perhaps learned something from abroad. Had he sent in the police initially, he might have provoked the same kind of response that de Gaulle's government met with in France.

In Czechoslovakia, both in the 'Czech spring', and in the movement of opposition to the Russian invasion of August 1968, students played a part, but never one that differentiated them significantly from the rest of the population's resistance.

The autumn of 1968 saw two other significant movements. In Mexico, the late 1960s witnessed the emergence of an urban counter-culture, $\mathrm{La}$ Onda (The Wave), involving coffee-houses, pot, rock music, new clothing and hair styles, all of them subject to regular police raids and repression. By the spring of 1968 there were huge protests. More than 100,000 in Mexico City participated in demonstrations which reached beyond students to teachers, public employees, even some small business owners. The movement declined somewhat over the summer, due in part to uncertainty about the way forward. Then came the appalling event of 3 October 1968, only days before the opening of the Olympic Games. A demonstration of between five and fifteen thousand marched against government heavyhandedness. In the Plaza of Tlatelolco, the demonstrators were deliberately fired on by 5,000 security and military police, with at least 200 killed, several thousand more injured, and 2,000 arrested and tortured. If the massacre silenced the movement for some time, it damaged the legitimacy of the ruling PRI, in ways that were felt for decades after (Zirakzadeh, 2006).

In Northern Ireland's sectarian Orange state, it was students who first formed the nascent Civil Rights Movement, whose demonstrations were 
savagely repressed, provoking rioting and sectarian attacks on Catholic communities. The British army was soon drawn in, and Northern Ireland entered a period of drawn-out civil war in which any space for specifically student movements was massively restricted.

Back in the United States, if the example of the Berkeley movement had been slow to spread, Black students at some of America's elite African-American universities were involved in successful campus protests which spread from opposition to segregated business establishments to challenges to the college curricula. Students at Columbia University in New York occupied administration buildings in protest at the University's links with Department of Defense contracts connected with the Vietnam War and, simultaneously, against the University's plans to take over land occupied by Black people's housing to build a University gymnasium. The Columbia struggle was scarred at times with factional infighting, and involved at least two pitched battles with New York police (Boren, 2001: 172-6). 1968 saw student rebellion return to Berkeley for the second time, and also generalize across much of the university sector. In the academic year 1968-9 70 per cent of private universities and 43 per cent of public universities reported 'severe student unrest', often involving battles with the police. The climax of the American student protest movement came in spring 1970. Students at Kent State University in Ohio organized a protest in the wake of the US bombing of Cambodia. When the National Guard were sent onto the campus, they shot dead four students and injured nine more on 4 May. $^{32}$ The shock of this event set off America's largest ever student protest, involving some four million students and reaching into high schools and even junior high schools. Two weeks later, local police killed two black students at Jackson State University in Mississippi, forcing President Nixon to order a federal inquiry (Spofford 1988). ${ }^{33}$ It would take America's final retreat from Vietnam, in 1975, to bring America's student rebellions finally to an end.

\section{The Student Left}

The development of student movements, and the radicalization that accompanied them, was the chief source of a 'new left', especially within western capitalism. While the particular shape and tempo in each country was different, and conditioned partly by developments outside the universities

\footnotetext{
32 There is a website devoted to the events at Kent State at http://www.may4.org/.

${ }^{33}$ See also www.aaregistry.com/african_american_history/1660/Killings_at_Jackson_State_University.
} 
- and especially by the specific domestic pattern of working-class struggle there were some similarities. Of all the movements in this period, it was perhaps the student movement which most tended to pick up ideas across national borders. Students were relatively mobile geographically, and quick to pick up ideas from other student insurgencies. ${ }^{34}$

Anyone moving to the left in the 1960s had to sort out some kind of position on a whole number of critical international and national questions. In the Cold War, they must choose whether to support 'Moscow' or reject both the USA and the USSR. With struggles continuing in colonial and semicolonial territories, they must decide whether to support national liberation movements, and - if so - whether to accept or criticise the 'socialist' claims that these movements, or their successor states, regularly made. They had to take a stance with respect to the increasingly overt pro-capitalist character of social-democratic parties, and to the practical reformism of western Communist Parties. If, as many did, they looked for 'revolutionary' answers, they still had to determine an attitude to the appeals of Maoism as a current apparently critical of Russian communism, and with it the 'guerrilla' politics associated with the name of Che Guevara. Crucially, they must assess the potential for radical and even revolutionary activity and organization among workers in the advanced capitalist states, after two decades of sustained economic boom and rising living standards. Plus, in the United States civil rights movement, but also in Northern Ireland, there were questions about the role of organized religion in social struggles. All these, and other issues, were fiercely debated, and provided the basis for a very fractious left scene.

As we've seen, in Europe the predominant intellectual influences came from figures like Herbert Marcuse, Frantz Fanon and Che Guevara, with Maoism also gaining a major influence. In the USA, where Draper had commented in 1965 on the 'non-ideological' nature of much student radicalism, the emerging national student movement, Students for a Democratic Society, faced a choice, Draper suggested, between 'permeationism' and 'left opposition'. Where the previous generation of American radicals had mostly plumped for 'permeation' of the Democratic Party, the new generation rejected this. But what, then, should they do? SDS, which still went 'half the way with LBJ' in 1964, radicalised, but not towards working-class

\footnotetext{
${ }^{34}$ A small example. Students at Manchester University learned that Warsaw students had responded to an official Communist Party speaker, not by heckling him but by applauding his every word with ironic over-enthusiasm. The next speaker in Manchester from the Conservative Party was greeted with similar 'enthusiasm', and quite drowned out by the ironic singing of patriotic songs.
} 
politics. The SDS's Tom Hayden explained, in terms German radical students would have understood,

[...] the traditional left expectation of irreconcilable and clashing class interests has been defied. It appears that the American elite has discovered a long-term way to stabilize or cushion the contradictions of our society. [Hence the only way to break elite control is] [...] to oppose American barbarism with new structures and opposing identities. These are created by people whose need to understand their society and govern their own existence has somehow not been canceled by the psychological damage they have received.

Who might these people be? In America, the intellectuals (C. Wright Mills's last hope) disappointed, students initially attempted to organize 'the poor', rather as SNCC was seeking to organise poor blacks. However, the results of the 'community organising' work that SDS undertook were disappointing, and soon SDS was back on the campuses. The new left did not immediately identify itself with any concrete alternative to the American 'democracy' it found increasingly implausible. Paul Potter, president of SDS, refused to give a name to 'the system' in 1965, and the following year Carl Oglesby called it 'corporate liberalism'. Potter later wrote that he had deliberately not called it 'capitalism' on the grounds that the term was inadequate - 'a hollow, dead word tied to the thirties and a movement that had used it freely but without comprehending it. [...] I wanted ambiguity [...]. I sensed there was something new afoot in the world $[. .$.$] that made rejection of the old terminology$ part of the new hope for radical change in America' (Epstein, 1991). Epstein comments:

The open, nonideological vocabulary of SDS allowed for creative exploration of new ideas but also imposed an innocence on the theoretical language of the left, reflecting the movement's reluctance to commit itself to particular goals or to find a particular standpoint from which a revolutionary strategy could be put forward.

However, when SDS became something like a mass movement and simultaneously turned toward revolution in the later 1960s, innocence meant lack of sophistication and a vulnerability to the revolutionary posturing of... sects'. In the absence of any theoretical alternative, the movement was swept up by models of revolution predominantly based on Maoist theorizing and Third World experience (Epstein, 1991: 41-3). The tensions led to a conference in 1969, which split SDS into a system 
of competing sects. ${ }^{35}$ Authoritarianism and moralism were rampant in the movement and not confined to the sects. Feminism, as Epstein comments, might have offered the strongest basis for a critique of these tendencies, except that it was also infected by them.

Throughout the movement, politics and personal morality could easily become coercive. Admiration for Third World revolutions and a growing understanding of the oppressive role of the United States produced widespread guilt feelings, which tended to undermine good judgement. To the degree that political activity was an attempt to prove one's dedication (or test that of others), clear-minded evaluation of the movement's aims and strategies became difficult. Emulation of Third World models created havoc by encouraging a militaristic style and undermining the values to which the early New Left had dedicated itself, damaging the movement's relations with allies and potential allies outside the student and youth milieu. (Epstein, 1991: 45)

A different outcome would have required an American left that saw itself more as part of a long-term tradition, which realised that revolution was not due immediately, and could therefore think creatively about what a commitment to the revolutionizing of American society might entail. Epstein is careful to dissociate her judgments on the period from those who think that the turn to revolution was itself a mistake, for that 'misses what was legitimate about the impulse that shaped those politics' (Epstein, 1991: 47). As it was, the best that could be hoped was, as Sam Friedman suggested, that the 'system of sects' would winnow itself down by competition, in a process that might, with luck, produce a winner with a clearer vision of a way forward for the US left (Friedman, 1984-5)..$^{36}$ The winnowing certainly happened, but no clear victor emerged. By the later 1970s the American left was much reduced, and 'permeationism' was again attracting many former radicals.

Not only did it matter what general views students developed, but so too did the kinds of political organizations they formed or joined. For these shaped their activities, their ideas, their views about organizational questions, their exclusiveness or otherwise. The worst extremes were represented by those who turned away from any kind of effort at persuasion and involvement of others, towards the closed world of terrorist violence. While some on the left professed to admire them, groups like the Red Brigades in Italy, The Red Army Faction in Germany or Weatherman in the USA

\footnotetext{
35 There is a biased, but revealing, report by an undercover agent who attended SDS's final Chicago convention in 1969, at http://martinrealm.org/documents/radical/sixties1.html.

${ }^{36}$ See also the remarks on the elimination of arbitrary groups by competition in Gramsci, 1971:341.
} 
represented an extremely elitist politics, which wrote off the majority, working class or otherwise, as a source of any significant social initiative. The Maoist groups, whose largest representative organizations were in Italy and North America, modelled themselves on a form of revised Stalinist organization, with very top-down leadership styles. By the second half of the 1970s they were imploding, as heady illusions in the "cultural revolution' in China faded with the rise of Deng Xiaoping and then the Vietnamese invasion of Cambodia and China's war with Vietnam. These organizations had been least able to relate sympathetically to the growth of second-wave feminism, and therefore also to a working class whose gender composition was changing quite rapidly. Numbers of them, with previously quite large memberships, formally wound up in the later 1970s. ${ }^{37}$

Whatever their several failings, the combined forces of the revolutionary left in the advanced capitalist countries were insufficient to win hegemony within larger movements against the combined forces, not simply of states, but crucially of the inherited reformist parties and unions. Any judgment about them has to be framed by that elementary fact: in the conditions of the time, they could not have won. Rather, they have to be assessed in terms of their capacity to lay significant foundations for revolutionary organizations, which could survive disappointments and remain committed to seeking the total transformation of capitalism. Outside a few organizations deriving from Trotskyist traditions, most of the revolutionary groups that were born from or expanded through the student movements failed. With unrealistic perspectives and unsuitable organizational forms, their capacity to relate to the real complexity of the movements of the sixties and seventies was weak. Most left behind them little but a mood of disenchantment with the revolutionary project itself.

\section{The End of the Wave}

The late sixties and early seventies saw the term 'revolution' come back into fairly widespread use, and not only to describe events in Third World countries. The movements of the time initiated a boom in Marxist and radical publishing, not only from left organizations but also from bourgeois publishers who spotted a new market. After two decades of apparent postwar conformity in both West and East, a literature appeared that was more aware and more critical of the 'contradictions' in social development. Such literature was naturally more appealing, especially when it seemed possible that such contradictions might be resolved through adequate movement action, ideology and organization.

\footnotetext{
${ }^{37}$ For the European experience, see Harman, 1979.
} 
From the mid-1970s, however, confidence in the possibility of large-scale transformation from below began to wane. By the late 1970s, there was a widespread mood of rejection of left analyses and prescriptions. A more conservative trend in thought became predominant, marked by the increasing influence of 'post-structuralist' and 'post-modernist' ideas. These involved turning away from global solutions, indeed even from speaking of global problems - even though these problems, in real terms, were multiplying as the long postwar economic boom shuddered to a halt. Left-wing hopes in China ended with Mao's death, the overthrow of the Gang of Four and Deng Xiaoping's access to power. In France, celebrated in the pages of New Left Review during the late sixties and early seventies as the world centre of radical thought, the collapse of the Union of the Left went along with the rise of the nouveaux philosophes, former Maoist intellectuals who now denounced Marxism as a theory leading to the Gulag. By 1983, Perry Anderson could call Paris 'the capital of European intellectual reaction'.

If 1968 had been a 'highpoint' of the protest wave, the years 1974-6 marked its end. These years were marked by the stabilization of bourgeois rule everywhere, as ruling classes repaired their own structures and re-asserted their hegemony. In the US, the Ford and Carter Presidencies overcame the traumas of Vietnam and Watergate, kept their armed forces clear of any involvement in land wars, cut the FBI and CIA down to size, and offered amnesties to thousands of draft-dodgers and deserters, allowing dissidents to reintegrate into the mainstream. In Britain, Edward Heath's embattled conservative government was replaced by a Labour government that enjoyed whole-hearted cooperation from trade-union leaders, both right and 'left'. In southern Europe, Greece, Portugal and Spain all made 'democratic transitions' - in the Portuguese case only after a dramatic eighteen months of popular revolutionary movements - to parliamentary democracies, in which formerly persecuted political parties were permitted to play important roles. Italy's largest opposition party, the Communist Party, was finally allowed a say in government for the first time in thirty years. The 'managed transition' in Spain launched a series of comparable processes that affected much wider areas of the world, notably in Latin America, where military regimes negotiated 'soft democratizations' (Barker, 1998; Potter et al., 1997).

The mid-1970s restructuring of capital and its relationship with labour occurred against the background of the world's first significant postwar economic crisis, which combined international stagnation and rising inflation levels. At the very centre of world capitalism, New York City's bankers foreclosed on their loans, compelling an enormous down-sizing of the city's 
welfare and wages bill, and taking over the administration of the city's budget. The restructuring in Europe was achieved, not by direct repression, but by negotiated agreements with the leaders of social-democratic and communist unions and parties. The typical form of the agreement was a formal 'pact' between governments and the official leaders of labour movements, whether in Britain's 'Social Contract', Spain's 'Pact of Moncloa' or the 'Historic Compromise' effected by the Italian Communist Party under Enrico Berlinguer. The terms of the agreements were similar: in return for admission into the corridors of power, the official institutions of labour agreed to restrict and contain workers' demands, to demobilize popular resistance. The costs of the economic crisis were shifted onto labour's shoulders, all in the name of 'economic necessity', 'fighting inflation' and 'realism'. Many formerly militant trade unionists were disquieted and disoriented, but - with rising unemployment levels - the previous readiness to engage in 'rank and file', 'unofficial' and 'wildcat' strike action declined. The revolutionary left was unable to mobilize significant workplace resistance. In Britain, some workers drew an obvious conclusion from the disappointments of the Labour government: in 1979, seeing the Labour party, once the focus of their hopes, offering no more than the Tories, they voted Tory. Mrs Thatcher won the election.

In Italy, Lumley dates the final end of the protest wave in 1978, a year marked by the collapse and fragmentation of social movements and collective action, The New Left disintegrated, the unions were integrated into political system, the PCI formally accepted the 'historic compromise' and forfeited its oppositional role. This was the period of the temporary ascendancy of the Red Brigades, provoking further ideological crisis on the left. The women's movement, too, was affected. 1978-80 became known as 'the years of silence' (Lumley, 1990: 329).

These transformations did not, however, mean the end of all student movements. What they did was to 'normalise' them. From the beginning of the 1970s, in Britain, new kinds of issues mobilized student activists, now well used to the idea of collective action. Already by the early 1970s, the growing world economic crisis was inducing cutbacks in spending on higher education. As the British White Paper of 1972 put it, 'scope must be found for economies of scale' (Callinicos and Turner, 1975: 11). Rising inflation reduced the real value of student grants. Concerns with material questions became more prominent. So did student involvement with the national students union, which the sixties movements had largely ignored as irrelevant (Widgery, 1969). Where previously the NUS executive had been controlled by an alliance of Tories and right-wing Labour students, now a moderate 
left alliance (Communist Party and left Labour) took control. The Tory education minister in 1970-74 was Mrs Thatcher, who sought to prevent campus-based student unions from donating funds to strikers or to an antigovernment campaign defending free milk for school-children. A national campaign in defence of student union autonomy rallied large numbers of 'non-political' students. So too did the first national campaign over student grants, involving rent strikes and large demonstrations. These campaigns mobilized, not so much the older universities which had often been the storm centres of the sixties movements, but students from smaller colleges with a higher working-class presence. The Labour Government after 1974 brought huge cutbacks in capital spending on education, threatening everyday conditions in the colleges. The pressure of the cutbacks was felt hardest not in the older universities, but in the Polytechnics, the teacher training and further education colleges. The NUS 'left' leadership was now ideologically closer to the rest of the trade union leadership, and did no more than their older colleagues to lead a serious fight.

Across the face of advanced capitalism, higher education continued to expand the numbers of students. In practice, the previously relatively privileged situation of students declined further. So did their job prospects. In West Germany, the share of university graduates finding public-sector jobs tumbled from $60 \%$ in the early 1970 s to $25 \%$ by the end of the decade, and unemployment rates among graduates began to converge with those among the workforce generally (Zirakzadeh, 2006).

The steady strengthening of 'neo-liberalism' increasingly affected the situation in universities and colleges. Like the rest of social relations, the principles of 'marketization' were driven through higher education. Large parts of the sector were converted into 'training' institutions, increasingly subordinated to the immediate needs of capitalist business. Systems of state support for student grants were pared back or abolished, forcing increasing numbers of students to seek paid employment during their courses, and loading them up with debts (Callinicos, 2006).

\section{Retrospect and Prospect}

For a period in the 1960s, student movements and the social explosions they provoked on campuses across the world contributed more than any other social group to a changing social climate. Even if they were often brief and spasmodic, they altered the balance of ideas and values in advanced capitalist society. They also provided key cadres for other movements of the period. SNCC, for example, brought new life and impetus to the US civil rights movement at a moment when it seemed to be in the doldrums, 
and its ideas and activists inspired both the black power movement and, indirectly, the Black Panthers Party.

As well as directly political organizations, the student movement contributed strongly to the development of a 'cultural underground', which both provided some of the style of student politics and also acted as a substitute for politics for many. The student movement went along with a whole questioning of existing life styles and cultural assumptions, which sometimes shocked conservative forces in society (in 'communist' states at least as much as in the 'liberal' west) even more than overt student political action. Student movements massively amplified across the globe Bob Dylan's famous advice to older generations: 'Your sons and your daughters are beyond your command, The old order's rapidly changing [...]'.38 The 'cultural underground' reshaped attitudes to sexuality, not least amongst women. It drew on resources from outside student milieux, from workingclass and ghetto life, and fed into other movements of the time: into the wildcat strike movements in American factories around 1970, and the oppositional culture of US soldiers and marines in the later years of the war in Vietnam. It was, too, within student movements that the first serious stirrings of second-wave feminism were heard. Women members of SNCC wrote the first 'position paper' on feminism, and some of the earliest battles on the question were fought inside the very sexist atmosphere of the Students for a Democratic Society (Freeman, 1975).

Student movements radicalized numbers of their participants. The mechanisms involved have been well identified. Actual participation in collective action can be, as theorists have noted, a major source of changing social identities (Klandermans, 1992; Reicher, 1991; Reicher, 1996). A rising and expanding protest wave provides a dialogical setting in which information about self and society changes, potentially altering the balance between fatalism and acceptance on one side and a belief, on the other, that the social order can be both criticized and altered. Confidence in the possibilities of collective action can grow, along with openings of the imagination to new possibilities. What previously seemed 'fixed and unalterable' can come to seem motile and open to practical questioning. The sense of relative powerlessness, which infects the politics of everyday life, can be transmuted, quite quickly, into a more active and cheerful apprehension of new horizons of hope. The 'natural' and 'given' quality of the present order only begins to dissolve when it is challenged in practice, and when the challenge embodies, at least in half-recognizable embryo form, the shape of a different

38 'The times they are a-changing', recorded 24 October 1963. 
possible order. What Goodwyn wrote about participants in the birth of the Polish 'Solidarity' movement in 1980 also applies to the students who made the campus protests of the sixties and early seventies:

When individuals who have suddenly acquired an enhanced sense of self gaze upon others who have been part of the joint effort and who have acquired the same enhanced sense, a new kind of connection occurs. The feeling is distinctly one of personal achievement, but it also is organically a product of collective action.

The process, he notes, possesses 'an emotional significance that can yield surprising political breakthroughs'. Collective action and interaction can promote new forms of knowledge about how things can be achieved which were, previously, beyond the bounds of the possible. There is 'a merger of knowledge with emotion, a conjunction forced by lived experience'. (Goodwyn, 1991: 16, 192)

Such changes could occur more rapidly among students than other groups, because of their social situation. University is one of the few places that brings large groups of young people together on a semi-permanent basis. Few factories or offices are composed solely of young workers. Students' material responsibilities are less, and they are also less constrained in their forms of action than workers. If workers strike, they have to vote first, in order to be sure that they will carry the majority, for strike-breakers are a real practical problem. But it's easier for students: a significant minority can occupy some university buildings, and have a high impact, without necessarily worrying too much about the rest of the student body. Students possess the advantages in collective action of rapid potential organization, imagination and fluidity. Their structural disadvantages are that they lack traditions of permanent organization, and they can often find their struggles isolated from the rest of society. Their capacity to do lasting damage to capital and the state is limited, for they lack control of resources whose withholding can seriously hurt the powerful. Their struggles could sometimes appear like fireworks displays, momentarily dazzling but then as quickly disappearing.

When they were isolated, student revolts often left little lasting mark. They won some small concessions by way of minority 'representation' on university decision-making bodies, though they were always excluded from important subcommittees on matters like finance and staffing. They did succeed in breaking previous assumptions about university control - 'in loco parentis' - over aspects of their lives such as their housing patterns and sexual activity. 
It seems clear that student struggles alone did not detonate big social challenges to the status quo. It was when they combined with other social forces, sometimes only indirectly, that the largest challenges to the social order appeared. The general strike in France in May 1968 was perhaps the student movement's greatest single achievement, but they could only set it in motion without shaping its course. If we think of the student movements as 'initiators' (McAdam, 1995), there remains a problem for them, which is that of 'resources'. The fate of student movements is inherently tied to that of wider movements in society, whose tempos and patterns of activity may be much slower and different, but which can be decisive in a way that most student movements can't.

Student struggles of the 1960s and early 1970s sometimes paved the way for other movements, they provided imaginative energy, they provoked and excited. They produced some of the key cadres of a revived Left which was then tested in other struggles, beyond the limits of the campus. Umberto Eco's words about Italy apply far more generally:

Even though all visible traces of 1968 are gone, it profoundly changed the way all of us, at least in Europe, behave and relate to one another. Relations between bosses and workers, students and teachers, even children and parents, have opened up. They'll never be the same again. (cited Lumley, 1990: 2)

Since that time, much has changed. True, the influx of working-class students into higher education continued, but their experience became more and more like that of the 'training' institutions. The expansion of post-secondary education has continued, driven as in the sixties by the deepening of the so-called 'knowledge economy'. University research is tied, ever more closely, to the demands of business. The relatively privileged status of both academic staff and students has continued to decline, as their numbers have risen. More and more the 'precarity' that has been identified as a feature of the modern worker's condition has affected teachers and students alike. Within universities, the apparent gains of the sixties, in the formalization of partial 'democracy' on the campus, has receded as a new cadre of university administrators has developed and instituted increasingly 'top-down' forms of internal government - and demanded increasingly superior pay rewards for themselves (Callinicos, 2006).

What does this mean for student movements today? If France, home of the 'May events', is any guide, the changed conditions may also offer huge new possibilities. In April and May 2006 a spectacular movement of both university and high-school students, supported by the trade unions, 
succeeded in forcing the government to withdraw a new draft law. That law would have allowed employers to sack workers under the age of 26 during the first two years of their employment contracts. This was a serious defeat for the government's 'neo-liberal' plans to impose greater 'precarity' on the workforce. On this occasion, unlike 1968, relations between students and workers were much closer. As one commentator pointed out, these new possibilities were a response to the blurring of the old separation between educational institutions and workplaces in the latest phase of capitalist development. As education has been subjected increasingly to 'capitalist-commodity logic', so whole sectors of business have come to depend on full- and part-time students to staff their operations in fast food, call centres, supermarket chains and the like. The result, in France, was that ' $[t]$ his time the school and university youth has acted as part of the world of labour. [...] This "great transformation" has, of course (in comparison with 1968) not only made easier the link with workers but, above all, has given this an "organic" character, the character of the building of a common struggle, and not of an alliance or solidarity between separate movements' (Kouvelakis, 2006).

The future remains open, and potentially very interesting indeed.

\section{References}

Aya, Rod (1979), "Theories of Revolution Reconsidered: Contrasting Models of Collective Violence", Theory and Society, 8, 39-99.

Baluka, Edmund; Barker, Ewa (1977), "Workers' Struggles in Poland", International Socialism (first series), 94, 19-25.

Baran, Paul; Sweezy, Paul (1966), Monopoly Capitalism: An Essay on the American Economic and Social Order. New York: Monthly Review Press.

Barker, Colin (1986), Festival of the Oppressed: Solidarity, Reform and Revolution in Poland, 1980-1981. London: Bookmarks.

Barker, Colin (1998), "Some Notes on Revolution in the 20th Century", Journal of Area Studies, 13, 143-183.

Barker, Colin (2001), "Robert Michels and the Cruel Game", in Colin Barker; Alan Johnson; Michael Lavalette (eds.), Leadership in Social Movements. Manchester: Manchester UP, 24-43.

Barker, Colin; Cox, Laurence (2002), "'What Have the Romans Ever Done for Us?' Academic and Activist Forms of Movement Theorizing", in Colin Barker; Mike Tyldesley (eds.), Eighth International Conference on Alternative Futures and Popular Protest. Manchester: Manchester Metropolitan University, Volume 1 (http://www. iol.ie/ mazzoldi/toolsforchange/afpp/afpp8.html). 
Barnett, Anthony (1969), “A Revolutionary Student Movement”, New Left Review, 53, 42-53.

Bereday, George Z. F. (1967), “Student Unrest on Four Continents: Montreal, Ibadan, Warsaw, and Rangoon”, in Seymour Martin Lipset (ed.), Student Politics. New York: Basic Books, 97-123.

Birchall, Ian H. (1987), “France 1968: 'All Power to the Imagination!'”, in Colin Barker (ed.), Revolutionary Rebearsals. London: Bookmarks, 5-40.

Boren, Mark Edelman (2001), Student Resistance: A History of the Unruly Subject. London: Routledge.

Brinton, Crane (1965), The Anatomy of Revolution. New York: Vintage.

Budderberg, Manfred (1968), "The Student Movement in West Germany”, International Socialism (1st series), 33, 27-34.

Callinicos, Alex (2006), Universities in a Neoliberal World. London: Bookmarks.

Callinicos, Alex; Turner, Simon (1975), "The Student Movement Today", International Socialism (first series), 75, 9-15.

Cliff, Tony; Barker, Colin (1966), Incomes Policy, Legislation and Shop Stewards. Harrow Weald: London Industrial Shop Stewards Defence Committee.

Cliff, Tony; Birchall, Ian H (1968), France: The Struggle Goes On. London: International Socialists [reprinted in Tony Cliff (2001), Selected Writings, Volume 1: International Struggle and the Marxist Tradition. London: Bookmarks, 159-217].

Cockburn, Alexander (1969), "Introduction”, in Alexander Cockburn; Robin Blackburn (eds.), Student Power: Problems, Diagnosis, Action. Harmondsworth: Penguin, 7-21.

Crouch, Colin; Pizzorno, Alessandro (eds.) (1978), The Resurgence of Class Conflict in Western Europe since 1968. London: Macmillan (2 volumes).

Darlington, Ralph; Lyddon, Dave (2001), Glorious Summer. Class Struggle in Britain 1972. London: Bookmarks.

Davidson, Carl (1969), "Campaigning on the Campus”, in Alexander Cockburn; Robin Blackburn (eds.), Student Power: Problems, Diagnosis, Action. Harmondsworth: Penguin, 327-364.

Della Porta, Donatella (1995), Social Movements, Political Violence, and the State: A Comparative Analysis of Italy and Germany. Cambridge: Cambridge UP.

Della Porta, Donatella (1996), "Social Movements and the State: Thoughts on the Policing of Protest”, in John D. McCarthy; Doug McAdam; Mayer N. Zald (eds.), Comparative Perspectives on Social Movements: Political Opportunities, Mobilizing Structures, and Cultural Meanings. Cambridge: Cambridge UP, 62-92.

Donovan, Lord (1968), Royal Commission on Trade Unions and Employers Associations 1965-1968. London: HMSO, Cmnd. 3623.

Draper, Hal (1965), Berkeley: The New Student Revolt. New York: Grove Press.

Draper, Hal (1978), Karl Marx's Theory of Revolution. Volume II. The Politics of Social Classes. New York: Monthly Review Press. 
Epstein, Barbara (1991), Political Protest and Cultural Revolution: Nonviolent Direct Action in the 1970s and 1980s. Berkeley: University of California Press.

Fernbach, David (1969), "Strategy and Struggle”, New Left Review, 53, 37-41.

Frank, Andre Gunder Frank; Fuentes, Marta (1984), "On Studying the Cycles in Social Movements”, Research on Social Movements, Conflict and Change, 17, 173-196.

Freeman, Jo (1975), The Politics of Women's Liberation. London: Longman.

Friedman, Samuel R. (1984-5), "Mass Organizations and Sects in the American Student Movement and Its Aftermath", Humboldt Journal of Social Relations, 12(1), $1-23$.

Garson, Marvin (1965), “The Regents”, in Hal Draper (ed.), Berkeley: The New Student Revolt. New York: Grove Press, 215-221.

Ginsborg, Paul (1990), A History of Contemporary Italy. Society and Politics 1943-1988. London: Penguin.

Goodwin, Jeff; Jasper, James M.; Polletta, Francesca (2001), "Introduction: Why Emotions Matter”, in Jeff Goodwin et al. (eds.), Passionate Politics: Emotions and Social Movements. Chicago: Chicago UP, 1-24.

Goodwyn, Lawrence (1991), Breaking the Barrier: The Rise of Solidarity in Poland. New York: Oxford UP.

Gorz, Andre (1968), "Reform or Revolution”, in Ralph Miliband; John Saville (eds.), The Socialist Register 1968. London: Merlin, 111-144.

Gouldner, Alvin (1955), "Metaphysical Pathos and the Theory of Bureaucracy", American Political Science Review, 49, 496-507.

Gramsci, Antonio (1971), Selections from the Prison Notebooks. London: Lawrence and Wishart.

Halliday, Fred (1969), "Students of the World Unite", in Alexander Cockburn; Robin Blackburn (eds.), Student Power: Problems, Diagnosis, Solution. Harmondsworth: Penguin, 287-326.

Harman, Chris (1979), "Crisis of the European Revolutionary Left", International Socialism series 2, 4, 49-87.

Harman, Chris (1988), The Fire Last Time: 1968 and After. London: Bookmarks.

Harman, Chris et al. (1968), Education, Capitalism and the Student Revolt. London: International Socialism.

Heirich, Max (1970), The Beginning: Berkeley, 1964. New York: Columbia UP.

Johnson, Alan (1997), “New Track May Have to Be Laid': the "Special Class” and the Social Movement in the Marxism of Hal Draper", in Colin Barker; Mike Tyldesley (eds.), Third International Conference on "Alternative Futures and Popular Protest". Manchester: Manchester Metropolitan University.

Klandermans, Bert (1992), "The Social Construction of Protest and Multiorganisational Fields”, in Aldon D. Morris; Carol McClurg Mueller (eds.), Frontiers in Social Movement Theory. New Haven: Yale UP, 77-103. 
Kouvelakis, Stathis (2006), "France: from Revolt to Alternative”, International Socialist Tendency Discussion Bulletin, 8. Available in: <http//:www.istendency.net>.

Laba, Roman (1991), The Roots of Solidarity: A Political Sociology of Poland's Working-Class Democratization. Princeton: Princeton University Press.

Lipset, Seymour Martin; Altbach, Philip G. (1967), "Student Politics and Higher Education in the United States", in Seymour Martin Lipset (ed.), Student Politics. New York: Basic Books, 199-252.

Lumley, Robert (1990), States of Emergency. Cultures of Revolt in Italy from 1968 to 1978. London: Verso.

Luxemburg, Rosa (1986), The Mass Strike, the Political Party and the Trade Union. London: Bookmarks [1906].

Marcuse, Herbert (1964), One Dimensional Man: Studies in the Ideology of Advanced Industrial Society. London: Routledge and Kegan Paul.

McAdam, Doug (1982), Political Process and the Development of Black Insurgency, 1930-1970. Chicago: Chicago UP.

McAdam, Doug (1988), Freedom Summer. New York: Oxford UP.

McAdam, Doug, Tarrow, Sidney; Tilly, Charles (2002), Dynamics of Contention. Cambridge: Cambridge UP.

McPhail, Clark (1991), The Myth of the Madding Crowd. New York: Aldine de Gruyter. Mills, C. Wright (1960), The Causes of World War Three. New York: Ballantine.

Morris, Aldon D.; Herring, Cedric (1987), "Theory and Research in Social Movements: A Critical Review", Annual Review of Political Science, 2.

Payne, Charles M. (1995), I've Got the Light of Freedom: The Organizing Tradition and the Mississippi Freedom Struggles. Berkeley: University of California Press.

Polletta, Francesca (1994), "Strategy and Identity in 1960s Black Protest", Research in Social Movements, Conflict and Change, 17, 85-114.

Polletta, Francesca (2006), It Was Like A Fever: Storytelling in Protest and Politics. Chicago: University of Chicago Press.

Potter, David et al. (eds.) (1997), Democratization. Cambridge: Polity Press.

Regalia, Ida; Regini, M.; Reyneri, E. (1978), "Labour Conflicts and Industrial Relations in Italy", in Colin Crouch; Alexandro Pizzorno (eds.), The Resurgence of Class Conflict in Western Europe Since 1968, Volume 1, National Studies. London: Macmillan.

Reicher, Stephen (1991), "Politics of Crowd Psychology", The Psychologist, 487-491.

Reicher, Stephen (1996), "The Battle of Westminster: Developing the Social Identity Model of Crowd Behaviour in Order to Deal with the Initiation and Development of Collective Conflict”, European Journal of Social Psychology, 26, 115-134.

Robbins, Lord (1963), Higher Education. London: HMSO, Cmnd 2154.

Rule, James B. (1989), "Rationality and Non-Rationality in Militant Collective Action", Sociological Theory, 7(2), 145-160. 
Seabury, Paul (1967), "Student Freedom and the Republic of Scholars: Berlin and Berkeley”, in Seymour Martin Lipset (ed.), Student Politics. New York: Basic Books, 253-266.

Shawki, Ahmed (1990), "Black Liberation and Socialism in the United States", International Socialism (2nd series), 47, 3-110.

Spofford, Tim (1988), Lynch Street: The May 1970 Slayings at Jackson State. Kent, OH: Kent State University Press.

Stedman Jones, Gareth (1969), "The Meaning of the Student Revolt”, in Alexander Cockburn; Robin Blackburn (eds.), Student Power: Problems, Diagnosis, Action. Harmondsworth: Penguin, 25-56.

Tarrow, Sidney (1983), Struggling to Reform: Social Movements and Policy Change During Cycles of Protest. Ithaca, NY: Cornell University Western Societies Paper No. 15. Tarrow, Sidney (1989a), Democracy and Disorder: Protest and Politics in Italy 1965-1975. Oxford: Oxford UP.

Tarrow, Sidney (1989b), Struggle, Politics and Reform: Collective Action, Social Movements, and Cycles of Protest. Ithaca: Cornell University Press.

Tarrow, Sidney (1993), "Cycles of Collective Action: Between Moments of Madness and the Repertoire of Contention", Social Science History, 17(2).

Tarrow, Sidney (1994), Power in Movement: Social Movements, Collective Action and Politics. Cambridge: Cambridge UP.

Thompson, E. P. (ed.) (1970), Warwick University Ltd: Industry, Management and the Universities. Harmondsworth: Penguin Education Special.

Tilly, Charles (1978), From Mobilization to Revolution Reading, Mass.: Addison-Wesley. Tilly, Charles (1993), “Contentious Repertoires in Great Britain, 1758-1834”, Social Science History, 17(2), 253-280 [reprinted in Mark Traugott (ed.) (1995), Repertoires and Cycles of Collective Action. Durham NC: Duke University Press, 15-42].

Tilly, Charles (1995), Popular Contention in Great Britain 1758-1834. Cambridge, Mass: Harvard UP.

Triesman, David (1969), “The Impermanent Stronghold”, New Left Review, 53, 33-35. Weinberg, Jack (1965), “The Free Speech Movement and Civil Rights”, Campus CORElater January 1965 (http://www.fsm-a.org/stacks/weinberg.html).

Widgery, David (1969), "NUS - the Students' Muffler", in Alexander Cockburn; Robin Blackburn (eds.), Student Power: Problems, Diagnosis, Action. Harmondsworth: Penguin.

Wilcox, James (1969), “Two Tactics”, New Left Review, 53, 23-32.

Zirakzadeh, Cyrus Ernesto (2006), Social Movements in Politics: A Comparative Study. London: Longman. 